\title{
Mining and metallurgical wastes: a review of recycling and re-use practices
}

\author{
by E. Matinde*, G.S. Simate*, and S. Ndlovu*†
}

\begin{abstract}
Synopsis
Mining and metallurgical processes produce significant amounts of waste. In South Africa, mining and metallurgical wastes constitute one of the biggest challenges to the environment. If not managed properly, these types of wastes can result in irreversible damage to the environment and constitute a hazard to humans. Despite the environmental challenges associated with mining and metallurgical wastes, the mining and metal extraction industries can be integrated to form a circular economy model that promotes zero waste through the recycling and re-use of these waste materials. In other words, the different waste streams can in fact be considered as secondary sources of valuable minerals and metals. In this paper we review some of the research and emerging trends in the recycling and re-use of mining and metallurgical wastes. A brief overview is provided of how some of the key aspects of sustainability can be integrated into the teaching and research space in engineering sciences.

Keywords

mining and metallurgical wastes, circular economy, sustainability, recycling, re-use.
\end{abstract}

produced, in-process recycling, and finding new markets and applications in other sectors of the economy (Lottermoser, 2011; Environmental Protection Agency, 2015; World Steel Association, 2015; Ndlovu, Simate, and Matinde, 2017). As such, increasing the recycling and re-use of the different types of wastes is a potential panacea to the environmental and health challenges posed by these waste streams. Despite the environmental challenges associated with these types of wastes, the mining and metal extraction industries can be integrated to form a circular economy model that promotes zero waste through the re-use and recycling of these waste materials (Lottermoser, 2011; EPA, 2015; World Steel Association, 2015; Ndlovu, Simate, and Matinde, 2017; Flanagán, Grail, and Johnson, 2016). The different waste streams can in fact be considered as secondary sources of valuable metals and other resources.

Circular economy, recyclability, recycling, and re-use have been identified as some of the emerging paradigms that can drive the multidimensional aspects of sustainability in the mining and metal extraction industries. In this context, a sustainable circular economy is defined as a transition where the value of products, materials, and resources is maintained in the economy for as long as possible, and the generation of waste minimized (European Commission, 2015; World Steel Association, 2015). The broad

* School of Chemical and Metallurgical Engineering, University of Witwatersrand, South Africa.

† DST/NRF SARChI: Hydrometallurgy and Sustainable Development, School of Chemical and Metallurgical Engineering, University of the Witwatersrand, South Africa.

(C) The Southern African Institute of Mining and Metallurgy, 2018. ISSN 2225-6253. This paper was first presented at the Society of Mining Professors 6th Regional Conference 2018, 12-13 March 2018, Birchwood Hotel and Conference Centre, Johannesburg, South Africa. 


\section{Mining and metallurgical wastes: a review of recycling and re-use practices}

objective of a circular economy model is to reduce the linear flow of materials through recycling and re-use in order to rejuvenate the life-cycle of a material (Ndlovu, Simate, and Matinde, 2017). Lottermoser (2011) defined the recycling of mine wastes as a practice that extracts new valuable resource ingredients, or uses the waste as feedstock, and/or converts the entire waste stream into a new valuable product. Recyclability refers to the amenability of waste materials to be captured and converted into a new material and/or re-used in the same capacity (Ndlovu, Simate, and Matinde, 2017). According to Ndlovu, Simate, and Matinde (2017), the recyclability of a waste material is driven by technological and economic factors. In essence, the recyclability of materials depends on the availability of methods and technologies as well as the existence of markets for the recycled products. Finally, the World Steel Association (2015) broadly defined the term re-use as using an object or material again, either for its original purpose or for a similar purpose, without significantly altering the physical form of the object or material. Although most of these terms are used loosely and interchangeably by various stakeholders, some of the short- and long-term benefits of recycling and re-use of mining and metal extraction wastes include (Lottermoser, 2011): (1) creating financial assets, (2) increasing resource efficiency by reducing the linear consumption of natural resources, (3) reducing waste production and accumulation, (4) encouraging innovation and growth of local industry spin-offs, (5) creating employment, and (6) shared responsibility and ownership over the environment.

In line with these emerging paradigms of environmental responsibility and sustainable development, the broad objective of this paper is to explore sustainable alternatives to the primary supply of metals from mined ores through recycling and re-use of mining and metal extraction wastes. In detail, this paper provides a critical review of the emerging body of knowledge on recycling and re-use of these waste materials. In addition, we propose potential approaches that can contribute to unlocking the economic value of mining and metallurgical wastes by integrating some of the key sustainability drivers into the teaching and learning of engineering sciences.

\section{Categories of mining, metallurgical, and industrial wastes}

Basically, waste is a complex, subjective, and sometimes a controversial issue and, in fact, a review of literature reveals an ongoing international debate on the definition of waste (Ndlovu, Simate, and Matinde, 2017). Nevertheless, waste is generally defined by many environmental bodies as any discarded, rejected, abandoned, unwanted, or surplus matter, whether or not intended for sale or for recycling, reprocessing, recovery, or purification by a separate operation from that which produced it (Ndlovu, Simate, and Matinde, 2017). Waste is generated in all sorts of ways, and its composition and volume depend largely on consumption patterns and the industrial and economic structures in place. Waste may exist in solid, liquid, or gaseous form. However, waste, in whatever form, is one of the world's largest concerns and gives rise to both public health and environmental concerns (Bian et al., 2012). Environmental threats may include contamination of groundwater and surface water by leachates, as well as air pollution from burning of waste that is not properly disposed of. Therefore, in the recent past, the effects of waste, particularly mining and metal extraction wastes, have been the focus of critical attention (Lottermoser, 2011; Bian et al., 2012; Reck and Graedel, 2012; Ndlovu, Simate, and Matinde, 2017).

Inasmuch as the generation of mining and metallurgical wastes is inevitable in the production of industrial materials, conventional waste management practices to date have focused on how to manage the way in which the waste is generated and disposed of (Hering, 2012). In fact, mining, metallurgical, and industrial wastes are considered to have little or no apparent economic use, and are thus usually discarded and/or landfilled (Lottermoser, 2011; Bian et al., 2012; Ndlovu, Simate, and Matinde, 2017). Despite protracted efforts to reduce the amount of waste produced by the mining and metallurgical industries, these types of wastes still constitute one of the world's largest waste streams (Bian et al., 2012). Table I provides an overview of some of the types of wastes produced in the mining and metals extraction industry (Lottermoser, 2011; Rankin, 2011; Ndlovu, Simate, and Matinde, 2017).

\section{Legislative framework governing mining and metallurgical wastes}

Over the years, environmental laws and social awareness programmes have been promulgated in order to mitigate the potential threats of mining and metallurgical wastes (Table II). Basically, these environmental and social regulations are of universal importance, and revolve around environmental protection, protection of local communities, and promotion of business ethics (Phadke et al., 2014; Ndlovu, Simate, and Matinde, 2017). Despite the lack of consensus, and varying degree of legislative scope and effectiveness, various regulations and policies have been enacted so as to control the disposal and/or recycling of these types of wastes (Kumar and Singh, 2013; EPA, 2015; Ndlovu, Simate, and Matinde, 2017). Table II shows some of the selected environmental policies and regulations from the USA, EU, and South African jurisdictions (European Commission, 2006, 2008, 2010a, 2010b; Environmental Protection Agency, 2015; Ndlovu, Simate, and Matinde, 2017).

Inasmuch as there are no agreed-upon quintessential guidelines or legislation on the management of mining and metallurgical wastes, the different legislations converge towards one objective of environmental protection and sustainability. Ironically, the Bill of Rights, as enshrined in Chapter 2 of the South African Constitution (Act No. 108 of 1996), clearly stipulates the universal rights of citizens to environmental protection while promoting economic and social development. Furthermore, the USA's RCRA (1976) and the European Commission's Extracting Waste (Mining) Directive (2006/21/EC) have a strong emphasis on sustainability. These legislations specifically require operators to draw up waste management plans for the minimization, treatment, metal recovery from, and disposal of mining and extractive wastes.

In addition to the specific directives, the European Commission has also drawn up extensive industrial emissions directives (IED, 2010/75/EU) (European Commission, 2010b). The principal focus of these directives 


\section{Mining and metallurgical wastes: a review of recycling and re-use practices}

\begin{tabular}{|c|c|}
\hline \multicolumn{2}{|c|}{ Overview of some of the types of wastes produced in the mining and metals extraction industry } \\
\hline Type of waste & Comment \\
\hline Overburden & $\begin{array}{l}\text { Soil and rock material removed to access mineral deposits, and which is usually stockpiled. Overburden generally } \\
\text { has low potential for environmental contamination, but may be associated with acid rock drainage. }\end{array}$ \\
\hline Waste rock & $\begin{array}{l}\text { Contains minerals in concentrations considered too low to be economically extracted. Waste rock has a } \\
\text { heterogeneous mineralogical composition, chemical, and physical characteristics due to deposition of the wastes } \\
\text { from different mine sources. Depending on the mineral being extracted, waste rock is problematic due to the } \\
\text { formation of acid rock (mine) drainage. }\end{array}$ \\
\hline Mineral beneficiation tailings & $\begin{array}{l}\text { Fine barren rock that remains after extracting the valuable components. Tailings can also contain residual chemicals } \\
\text { and are usually deposited in the form of water-based slurry into tailings ponds. }\end{array}$ \\
\hline Metallurgical slags & $\begin{array}{l}\text { Glass-like or amorphous materials produced as by-products in the smelting and refining of metals. Although some } \\
\text { slags such as blast furnace slags can be environmentally benign and have found widespread applications in the } \\
\text { construction and agricultural industries, the presence of entrained and/or dissolved heavy metals presents } \\
\text { challenges to re-use. }\end{array}$ \\
\hline Waste water & $\begin{array}{l}\text { Emanates from a number of processes, with varying degrees of quality and environmental contamination potential. } \\
\text { Typical examples include minewater, process (mill) water, leachate (containing dissolved minerals, chemicals and/or } \\
\text { metals), effluent (process water discharged into surface water, often after treatment), and mine drainage water } \\
\text { (surface or groundwater with the potential to flow off the mine or industrial site). }\end{array}$ \\
\hline Water treatment sludge & $\begin{array}{l}\text { Semi-solid residue or slurry remaining after on-site treatment of mine and industrial water and waste water. Sludge } \\
\text { may be contaminated with heavy metals and other residual chemicals. The recycling and recovery of valuable metals } \\
\text { from mining and industrial sludges is being extensively explored. Depending on the processes, waste treatment } \\
\text { sludges are classified as hazardous materials. }\end{array}$ \\
\hline Acid mine drainage (AMD) & $\begin{array}{l}\text { Generated from mine waste rocks, tailings, and/or mine structures such as closed, active, or abandoned pits and } \\
\text { underground workings. }\end{array}$ \\
\hline Gaseous and particulate emissions & $\begin{array}{l}\text { Atmospheric emissions in the form of particulate dusts and toxic gases such as } \mathrm{SO}_{x}, \mathrm{NO}_{x}, \mathrm{CO} \mathrm{CO}_{2} \text {, organometallic } \\
\text { compounds, polychlorinated-p-dibenzodioxins and dibenzofurans (PCCD/Fs) emitted during the high-temperature } \\
\text { chemical processing of metals. These emissions are classified as hazardous materials in most jurisdictions due to the } \\
\text { presence of entrained toxic heavy metals, toxic organometallic compounds, and PCCD/Fs. }\end{array}$ \\
\hline Post-consumer waste & $\begin{array}{l}\text { Waste material generated by households or commercial, industrial, and institutional facilities in their role as end-users } \\
\text { of the products, which can no longer be used for its initial purposes, e.g. e-waste. }\end{array}$ \\
\hline
\end{tabular}

is to provide the best available techniques (BATs) and emerging techniques towards the reduction, recycling, and reuse of various waste streams across various industries (European Commission, 2010a, 2010b). In South Africa, for example, the various Acts clearly mandate the need for environmental responsibility with respect to air, water, and ground contamination, and further emphasize the mandatory rehabilitation of the affected environment. Globally, the convergence of the discrete legislations in these various jurisdictions has since resulted in a standardized ISO 14000 series, the main objective of which is to provide a standardized and effective management system.

\section{Recycling and re-use: ongoing research and emerging trends}

As discussed earlier, the circular economy model mandates the reduction, recycling and re-use of mining and metallurgical wastes. Based on the categories of wastes highlighted in Table I, the following sections outline the typical recycling and re-use opportunities of selected categories of mining and metal extraction wastes based on the emerging paradigms of converting wastes to valuable resources.

\section{Waste rock, overburden, and beneficiation waste}

As indicated in Table I, waste rock and overburden originate from materials overlying the area to be mined and which are moved in order to gain access to the orebody. These materials range from being barren (e.g., waste rock) to containing minerals at concentrations that are considered too low to be economically extracted (e.g., overburden). Mineral beneficiation waste, on the other hand, refers to tailings and/or residual materials generated from the mineral beneficiation processes (Ndlovu, Simate, and Matinde, 2017). Basically, mineral beneficiation wastes consist of rock, soil, loose sediment, and fine to ultrafine particles (Lottermoser, 2011; Bian et al., 2012; Ndlovu, Simate, and Matinde, 2017). Corollary to waste rock and overburden, the mineralogical characteristics of beneficiation wastes are usually highly heterogeneous as a result of the deposition of waste streams arising from different stages in the processing chain(Bian et al., 2012; Edraki et al., 2014). Furthermore, the amounts and complexity of waste rock, overburden, and beneficiation wastes vary significantly depending on the type of commodity, physical, and chemical composition of the mineralization, and the mining and processing methods used (Lottermoser, 2011; Bian et al., 2012; Flanagán, Grail, and Johnson, 2016; Ndlovu, Simate, and Matinde, 2017).

Millions of tons of waste rock, overburden, and beneficiation wastes are produced by the global mining industry. Due to their low intrinsic value, and the remote location of most mining operations, over $95 \%$ of these materials end up being disposed in landfills (Lottermoser, 2011; Bian et al., 2012; Flanagán, Grail, and Johnson, 2016; Ndlovu, Simate, and Matinde, 2017). However, disposal is associated with environmental challenges such as acid rock drainage, airborne dust emissions, and contamination of surface- and groundwater sources. Although these materials are generally classified as non-hazardous, increasing their 


\section{Mining and metallurgical wastes: a review of recycling and re-use practices}

\begin{tabular}{|c|c|c|}
\hline \multicolumn{3}{|c|}{$\begin{array}{l}\text { Table II } \\
\text { Overview of relevant waste management policies and regulations from selected jurisdictions }\end{array}$} \\
\hline Jurisdiction & Legislation & Content \\
\hline \multirow[t]{4}{*}{$\begin{array}{l}\text { USA (Environmental } \\
\text { Protection Agency, 2015) }\end{array}$} & $\begin{array}{l}\text { National Environmental } \\
\text { Policy Act (1970) }\end{array}$ & $\begin{array}{l}\text { Mandates environmental impact assessments (EIAs) for all economic activities that can } \\
\text { impact the environment. Applies to mining operations that require Federal approval. }\end{array}$ \\
\hline & $\begin{array}{l}\text { Resource Conservation and } \\
\text { Recovery Act (1976) }\end{array}$ & $\begin{array}{l}\text { Conserving of natural resources and reducing the amounts of wastes generated. } \\
\text { Ensures holistic waste management practices to protect the environment, and applies to } \\
\text { categories such as municipal solid waste landfills, hazardous waste generation, and } \\
\text { transportation, storage, and disposal facilities. }\end{array}$ \\
\hline & $\begin{array}{l}\text { Comprehensive Environmental } \\
\text { Response, Compensation and } \\
\text { Liability Act (1980) }\end{array}$ & $\begin{array}{l}\text { Requires operations to report inventory of chemicals handled and release of hazardous } \\
\text { substances to the environment, and mandates clean-up of sites where hazardous } \\
\text { substances are found. Amended to include mining, milling, and smelter wastes that } \\
\text { were not covered by the RCRA (1976). }\end{array}$ \\
\hline & Clean Air Act (1970) & $\begin{array}{l}\text { Addresses airborne pollution that may potentially cause harm to humans or natural } \\
\text { resources, e.g., dust emissions from operations or tailings disposal, exhaust emissions } \\
\text { from heavy equipment, and emissions from processing facilities such as smelters. }\end{array}$ \\
\hline \multirow{5}{*}{$\begin{array}{l}\text { European Union } \\
\text { (European Commission, } \\
\text { 2010a, 2010b; 2015) }\end{array}$} & \multirow{5}{*}{$\begin{array}{l}\text { The European Commission (EC) } \\
\text { has promulgated various } \\
\text { environmental directives } \\
\text { governing mining, metallurgical, } \\
\text { and industrial processes } \\
\text { in member states }\end{array}$} & Environmental Assessment Directive - similar to NEPA (1970). \\
\hline & & Water Framework Directive for protection of surface and groundwater sources. \\
\hline & & $\begin{array}{l}\text { Waste Framework (2006/12/EC), Hazardous Waste (91/689/EEC) and Landfill } \\
\text { (99/31/EC) directives - similar to RCRA (1976). }\end{array}$ \\
\hline & & $\begin{array}{l}\text { Extracting Waste (Mining) Directive (2006/21/EC) - similar to RCRA (1976). Operators } \\
\text { mandated to draw up extractive waste management plan (EWMP) for the minimization, } \\
\text { treatment, recovery, and disposal of extractive waste (emphasis on sustainable } \\
\text { development) (European Commission, 2006). }\end{array}$ \\
\hline & & $\begin{array}{l}\text { Industrial Emissions Directive (IED, 2010/75/EU) - similar to RCRA (1976). Principal } \\
\text { focus on best available techniques (BATs) and emerging techniques in waste } \\
\text { management across various industries (European Commission, 2010a, 2010b). }\end{array}$ \\
\hline \multirow[t]{5}{*}{ South Africa } & $\begin{array}{l}\text { Bill of Rights, Chapter } 2 \text { of } \\
\text { the Constitution } \\
\text { (Act No. } 108 \text { of 1996) }\end{array}$ & $\begin{array}{l}\text { Universal right to environmental protection through reasonable and other measures that } \\
\text { prevent pollution and secure ecological sustainable development and use of natural } \\
\text { resources while promoting economic and social development (Republic of South Africa, 2018) }\end{array}$ \\
\hline & $\begin{array}{l}\text { National Environmental } \\
\text { Management Act } \\
\text { (No. } 107 \text { of 1998) }\end{array}$ & $\begin{array}{l}\text { Framework and principles for sustainable development, and imposes duty of care and } \\
\text { remediation of environmental damage. Inclusive of sections that provide legal authority to } \\
\text { enforce environmental laws and private liability/prosecution (Department of Water and } \\
\text { Environment, 2010). }\end{array}$ \\
\hline & $\begin{array}{l}\text { National Water Act } \\
\text { (No. } 36 \text { of 1998) }\end{array}$ & $\begin{array}{l}\text { Integrity of water resources. Provides a hierarchy of priorities for mine water management in } \\
\text { terms of pollution prevention, water re-use or reclamation, and water treatment and discharge } \\
\text { (Department of Water and Environment, 2010). }\end{array}$ \\
\hline & Minerals Act (Act 50 of 1991) & $\begin{array}{l}\text { Statutory instrument for enforcing environmental protection, management of environmental } \\
\text { impacts, and the rehabilitation of affected environments (Republic of South Africa, 1991). }\end{array}$ \\
\hline & Air Quality Act (No. 39 of 2004) & $\begin{array}{l}\text { Prescribes measures to control air quality, including, but not limited to, the emission of } \\
\text { respirable and non-respirable dusts and their control and minimization through cleaner } \\
\text { technologies and cleaner production practices. }\end{array}$ \\
\hline Global (Ndlovu, Simate, & ISO 14000 series & $\begin{array}{l}\text { Guidelines and standards for environmental management systems, environmental auditing, } \\
\text { and Matinde, 2017)environmental performance and evaluation, environmental labels and } \\
\text { declarations, and life-cycle assessment. Established through consensus by national } \\
\text { standards bodies globally. }\end{array}$ \\
\hline
\end{tabular}

recycling and re-use potential can provide sustainable and cost-effective alternatives to mitigate the disposal and waste management challenges.

To date, extensive research has been conducted in order to mitigate the environmental impacts, as well as increasing the valorisation potential, of waste rock, overburden, and beneficiation wastes (Lottermoser, 2011; Bian et al., 2012; Lébre and Corder, 2015; Flanagán, Grail, and Johnson, 2016; Ndlovu, Simate, and Matinde, 2017; Gorakhki and Bareither, 2017). In addition to the widely adopted uses such as feedstock for cement, concrete, and aggregates in construction industry, waste rock and overburden can also be re-used as low-grade resources of valuable minerals and metals, as backfill materials for open voids, as landscaping materials, as capping materials for waste repositories, and as substrates for mine revegetation (Lottermoser, 2011; Bian et al., 2012). Other waste streams such as mine drainage sludges can be economically reprocessed to extract metals and mineral compounds, or can be re-used as flocculants and/or adsorbents to remove phosphates from sewage and agricultural effluents, as well as soil additives in agriculture. Beneficiation tailings, on the other hand, can be reprocessed to extract metals and metals compounds, while sand-rich tailings can be mixed with cement and used as backfill in underground mines. Clay-rich tailings can be used as amendments to sandy soils and for the manufacture of bricks, cement, floor tiles, sanitary ware, and porcelains (Lottermoser, 2011). Furthermore, Lottermoser (2011) proposed the potential use of ultramafic tailings in the production of glass and rock wool, and phlogopite-rich tailings for use in sewage treatment. Nevertheless, the proposed re-use opportunities entail their own challenges. For example, the heterogeneous composition and complex mineralogy of these materials may affect the physical and 


\section{Mining and metallurgical wastes: a review of recycling and re-use practices}

chemical properties of intended products and processes. Furthermore, mining and beneficiation wastes may contain elevated amounts of transition metal elements, toxic elements, and reactive minerals, which can contaminate the environment (Lottermoser, 2011; Bian et al., 2012). The low intrinsic value may further be exacerbated by the remote location of most mining operations and distance from mine site to potential markets (Lottermoser, 2011; Bian et al., 2012).

\section{Metal recovery from acid mine drainage}

Acid mine drainage (AMD) is an environmental problem related to the release of acidic, sulphate- and metalcontaining waste water into the environment. AMD is generated when sulphide-bearing minerals such as pyrite $\left(\mathrm{FeS}_{2}\right)$ are exposed to both oxygen and water, as well as the presence of acidophilic chemolithotrophic microorganisms. In general, the oxidation of $\mathrm{FeS}_{2}$ in the presence of oxygen and water takes place as depicted in Equation [1] (Simate and Ndlovu, 2014):

$$
2 \mathrm{FeS}_{2}+7 \mathrm{O}_{2}+2 \mathrm{H}_{2} \mathrm{O} \rightarrow 2 \mathrm{Fe}^{2+}+4 \mathrm{SO}_{4}^{2-}+4 \mathrm{H}^{+}
$$

AMD may also be generated from various sources such as mine waste rock, tailings, or mine structures such as active, closed, or abandoned pits and underground workings (Simate and Ndlovu, 2014; Ndlovu, Simate, and Matinde, 2017).

The effects of untreated AMD on the health of humans, wildlife, plants, and aquatic species are well documented (Akcil and Koldas, 2006; Ma and Banfield, 2011; Simate and Ndlovu, 2014). Consequently, much research has been dedicated to finding remediation solutions for AMD. Basically, remediation techniques focus on the treatment of the already-produced AMD before it is discharged into water bodies (Chowdhury, Sarkar, and Datta, 2015). In principle, remediation technologies can be broadly categorized as active or passive. Further details of the remediation techniques are well documented by Johnson and Hallberg (2005). The challenge with the conventional remediation processes is that they generally result in new waste streams that would require further treatment and/or disposal. Furthermore, the treatment residues may still contain the elements and compounds removed from the mine drainage, as well as the additives dosed during the treatment processes (Simate and Ndlovu, 2014).

As already stated, AMD is rich in dissolved metal sulphates, which are formed in a complex process from the oxidation of pyrite and other sulphide minerals like pyrrhotite, marcasite, chalcocite, covellite, arsenopyrite, and chalcopyrite. Due to the need for metal-containing resources and increasingly stringent environmental conditions, AMD is currently being considered for metal recovery as part of the larger AMD remediation strategy (Nordstrom et al., 2017). In fact, there are several such techniques used to recover metals from AMD, and these are primarily driven by incentives such as (Simate and Ndlovu, 2014): (1) reducing the amounts of waste sludge and brine products that require handling and disposal and incur potential long-term environmental liabilities, (2) generation of revenue streams to partly or fully offset the ongoing treatment and metal recovery costs, and (3) contributing to the long-term sustainability of mine water treatment projects.
To date, the removal and/or recovery of metals as hydroxide precipitates from AMD using alkaline reagents (e.g. $\mathrm{NaOH})$ has been the most widely adopted method (Johnson and Hallberg, 2005; Balintova and Petrilakova, 2011). Unfortunately, this technique has several drawbacks, including the generation of large volumes of hazardous concentrated sludge (Macingova and Luptakova, 2012; Ndlovu, Simate, and Matinde, 2017), and the fact that the selective extraction of metals is very difficult (Simate and Ndlovu, 2014; Ndlovu, Simate, and Matinde, 2017). There are several other methods used to treat AMD and/or recover metals. These techniques, which will not be discussed in detail in this paper, include solvent extraction, reverse osmosis, ultrafiltration, electrodialysis, ion exchange/adsorption, and wetland treatments (Ndlovu, Simate, and Matinde, 2017).

It must be noted that, in the recent past, a paradigm shift has taken place in the way AMD is viewed. Basically, research interests have shifted towards the recovery of valuable materials from AMD, in addition to its remediation. Apart from valuable metals, there are other industrially and economically useful products that can be recovered from AMD treatment processes (Simate and Ndlovu, 2014). Typical examples include saleable products such as sulphur, sulphuric acid, pigments, and metal sulphates; production of electricity; alkaline earth compounds such as calcium carbonate and magnesium hydroxides; building and construction materials such as gypsum and cement; agricultural materials (e.g. fertilizer), adsorbents used in municipal and industrial wastewater treatment; and pigments (e.g. ferrihydrites).

\section{Metal recovery and recycling of metallurgical dusts}

Metallurgical dusts consist of heterogeneous mixtures of complex oxides from feed and process materials entrained in the off-gas from smelting and refining furnaces. Large volumes of these waste materials are produced in processes such as the blast furnace ironmaking process, raw material agglomeration (e.g., coke, sinter, and pellet plants), electric arc furnaces (EAFs), basic oxygen furnaces (BOFs), stainless steel refining, base metal smelting and converting, and in submerged arc furnaces (SAFs) for ferrochrome and ferromanganese production (Ma and Garbers-Craig, 2006; Ndlovu, Simate, and Matinde, 2017). The physico-chemical properties of metallurgical dusts vary greatly depending on the process design, process parameters, operational procedures, and the type of raw materials used (Nyirenda, 1991; Palencia et al., 1999; Beukes, van Zyl, and Ras, 2010; Tangstad, 2013; de Buzin, Heck, and Vilela, 2017). For example, about $7-45 \mathrm{~kg}$ of blast furnace particulate dusts containing 100-150 $\mathrm{g}$ of $\mathrm{Zn}$ are produced per ton of hot metal (tHM). These materials are classified as hazardous waste in most jurisdictions due to the presence of toxic metal elements such as $\mathrm{Pb}, \mathrm{Cr}, \mathrm{Zn}$, and $\mathrm{Cd}$, and as such, cannot be disposed of in landfills without some form of pretreatment and/or stabilization (Nyirenda, 1991; European Commission, 2008; 2010a, 2010b; Beukes, van Zyl, and Ras, 2010;

Environmental Protection Agency, 2015; de Buzin, Heck, and Vilela, 2017; Ndlovu, Simate, and Matinde, 2017). Furthermore, metallurgical dusts are extremely fine and difficult to handle (Palencia et al., 1999; de Buzin, Heck, and Vilela, 2017). Despite these materials being rich in valuable 


\section{Mining and metallurgical wastes: a review of recycling and re-use practices}

metals, their direct in-process recycling is usually constrained by the potential build-up of deleterious and volatile metal compounds in the process (Bian et al., 2012; Remus et al., 2013; Ndlovu, Simate, and Matinde, 2017). Table III summarizes some of the characteristic properties and the recycling options applicable to selected categories of metallurgical dusts (Remus et al., 2013; Lin et al., 2017; Ndlovu, Simate, and Matinde, 2017).

The metallurgical dusts produced in the iron and steel manufacturing processes, for example, consist mainly of heterogeneous mixtures of complex oxides of feed materials entrained in the off-gas. As a result, these materials tend to contain significant amounts of iron, reductants, and alloying elements. To date, several processes have been developed, or are being investigated, in order to recover valuable metallic elements contained in metallurgical dusts while ensuring an environmentally benign barren product. Generally, two process options exist for the recovery of value metals from ferrous metallurgical dusts: pyrometallurgical and hydrometallurgical processes. Pyrometallurgical processes use thermal energy to separate the desired metals from other materials based on the differences between oxidation potentials, melting points, vapour pressures, densities and/or miscibility of the dust components when melted (Abdullah, 2013). In contrast, in hydrometallurgical technologies the desired metals are separated using techniques that capitalize on differences between constituent solubilities and/or electrochemical properties while in aqueous solution (Abdullah, 2013).

\section{Metal recovery and recycling of ferrous metallurgical dusts using pyrometallurgical processes}

As indicated in Table III, the direct recycling of ferrous dusts is limited by the presence of volatile toxic metal compounds such as $\mathrm{Zn}, \mathrm{Cd}$, As, and $\mathrm{Pb}$. In steelmaking, for example, Znbearing compounds such zincite ( $\mathrm{ZnO}$ ) and franklinite $\left(\mathrm{ZnFe}_{2} \mathrm{O}_{4}\right)$ are particularly problematic due to the heavy reliance on use of galvanized steel scrap as feed to these processes. The pyrometallurgical processing of ferrous dusts revolves around the carbothermic reduction sequence $\mathrm{ZnFe}_{2} \mathrm{O}_{4(\mathrm{~s})} \rightarrow \mathrm{ZnO}(\mathrm{s})+\mathrm{Fe}_{2} \mathrm{O}_{3(s)} \rightarrow \mathrm{Zn}_{(v)}+\mathrm{Fe}_{(S)} \rightarrow$ of $\mathrm{ZnFe}_{2} \mathrm{O}_{4}$ in dusts, and the resultant volatilization of the zinc before recovery in the downstream condensers (Lin et al., 2017; Ndlovu, Simate, and Matinde, 2017).

Table III

Typical properties and the recycling and mitigation processes applicable to metallurgical dusts

\begin{tabular}{|c|c|c|c|}
\hline Category & Characteristics & Recycling and mitigation & Challenges to recyclability \\
\hline Blast furnace dusts & $\begin{array}{l}7-45 \mathrm{~kg} \text { of dust/ } \\
\text { tHM; } 100-150 \mathrm{~g} \\
\mathrm{Zn} / \mathrm{tHM}\end{array}$ & $\begin{array}{l}\text { Briquetting and in-process recycling } \\
\text { as additional sources of iron and carbon }\end{array}$ & \multirow[t]{3}{*}{$\begin{array}{l}\text { Recyclability limited by in-process build-up of volatile metal } \\
\text { compounds, organometallic compounds, and polychlorinated } \\
\text { dibenzo-p-dioxins and dibenzofurans (PCDD/Fs). Intricate } \\
\text { off-gas cleaning systems required but fugitive emissions may } \\
\text { still be problematic. }\end{array}$} \\
\hline Coke plant dusts & $\begin{array}{l}\text { Varies (approx. }>1 \mathrm{~kg} \\
\text { coke breeze/ton coke }\end{array}$ & $\begin{array}{l}\text { Additives in sinter plant as auxiliary } \\
\text { fuels and reductants }\end{array}$ & \\
\hline $\begin{array}{l}\text { Ferrous raw material } \\
\text { agglomeration }\end{array}$ & Varies & $\begin{array}{l}\text { Briquetting and in-process recycling as } \\
\text { well as auxiliary additives in the blast } \\
\text { furnace and EAFs. }\end{array}$ & \\
\hline $\begin{array}{l}\text { Basic oxygen furnace } \\
\text { (BOF) dusts }\end{array}$ & $\begin{array}{l}14-143 \mathrm{~kg} \text { dust/t } \\
\text { liquid steel } \\
0.75-24 \mathrm{~kg} / \mathrm{t} \text { liquid steel }\end{array}$ & \multirow[t]{3}{*}{$\begin{array}{l}\text { Briquetting and in-process recycling. } \\
\text { Metal recovery using pyrometallurgical, } \\
\text { hydrometallurgical and plasma processes. } \\
\text { Solidification and/or stabilization }\end{array}$} & \multirow[t]{3}{*}{$\begin{array}{l}\text { Controlled material as the long-term leachability behaviour of } \\
\text { toxic metal elements in stabilized/solidified dusts is largely } \\
\text { unknown. Recyclability limited by the in-process build-up of } \\
\text { volatile metal compounds, variable value-metal thresholds, } \\
\text { and the complex chemical and mineralogical characteristics } \\
\text { of the dusts. Additional metal recovery processes costly. }\end{array}$} \\
\hline $\begin{array}{l}\text { Electric arc furnace } \\
\text { dusts (EAFDs) }\end{array}$ & $\begin{array}{l}15-20 \mathrm{~kg} \text { dust/t } \\
\text { steel. Over } 8.5 \mathrm{Mt} \text { are } \\
\text { produced per year }\end{array}$ & & \\
\hline $\begin{array}{l}\text { Stainless steel- } \\
\text { making dusts }\end{array}$ & $10-70 \mathrm{~kg}$ dust/t steel & & \\
\hline $\begin{array}{l}\text { Submerged arc } \\
\text { furnace (HCFeCr) }\end{array}$ & $\begin{array}{l}18-25 \mathrm{~kg} \text { dust } / \mathrm{t} \\
\mathrm{HCFe} \mathrm{Cr}\end{array}$ & \multirow[t]{2}{*}{$\begin{array}{l}\text { Process-integrated dust recycling systems. } \\
\text { Emissions reduction by mandatory } \\
\text { adoption of closedfurnaces, agglomeration } \\
\text { of feed, use of intricate wet scrubbing } \\
\text { systems, and control of raw material } \\
\text { quality and process parameters. }\end{array}$} & \multirow[t]{2}{*}{$\begin{array}{l}\text { Recyclability limited by in-process build-up of volatile metal } \\
\text { compounds and variable value-metal thresholds. Fugitive } \\
\text { emissions still problematic. Intricate wet scrubbing systems } \\
\text { costly and may not always be available. }\end{array}$} \\
\hline $\begin{array}{l}\text { Submerged arc } \\
\text { furnace (HCFeMn) }\end{array}$ & $\begin{array}{l}\text { Up to } 25 \text { wt\% Mn and } \\
\text { varying amounts of } \\
\text { volatile metals. }\end{array}$ & & \\
\hline $\begin{array}{l}\text { Base metals (copper) } \\
\text { smelter dusts }\end{array}$ & $\begin{array}{l}\text { Up to } 30 \text { wt.\% } \mathrm{Cu} \text { and } \\
\text { high amounts of } \mathrm{Fe}, \mathrm{S} \text {, } \\
\mathrm{Zn} \text {, and metalloids } \\
(\mathrm{As}, \mathrm{Sb}, \mathrm{Pb}, \mathrm{Cd}, \mathrm{Bi})\end{array}$ & $\begin{array}{l}\text { In-process recycling of smelter dusts. } \\
\text { Metal recovery using conventional } \\
\text { pyrometallurgical and hydrometallurgical } \\
\text { processes, or a combination of both. }\end{array}$ & $\begin{array}{l}\text { Recyclability of smelter dusts is limited by build-up of } \\
\text { deleterious, volatile toxic metals (e.g., (As, } \mathrm{Sb}, \mathrm{Pb} \text {, } \\
\mathrm{Cd}, \mathrm{Bi}) \text {, low value-metal thresholds, and the complex } \\
\text { chemical and mineralogical characteristics of the dusts. }\end{array}$ \\
\hline $\begin{array}{l}\text { PGM smelter and } \\
\text { converter dusts }\end{array}$ & $\begin{array}{l}\text { Varying amounts of } \\
\text { entrained PGMs, Fe, S, } \\
\text { Zn, and metalloids } \\
(\mathrm{As}, \mathrm{Sb}, \mathrm{Pb}, \mathrm{Cd}, \mathrm{Bi})\end{array}$ & & \\
\hline
\end{tabular}




\section{Mining and metallurgical wastes: a review of recycling and re-use practices}

To date, several pyrometallurgical approaches have been extensively applied globally in the economic recycling of ferrous metallurgical dusts. Table IV summarizes some of the processes for metal recovery and recycling of common metallurgical dusts (Palencia et al., 1999; Lin et al., 2017; Ndlovu, Simate, and Matinde, 2017).

\section{Metal recovery and recycling from metallurgical dusts using hydrometallurgical processes}

The major advantages of the pyrometallurgical processes developed so far lie in their ability to economically process metallurgical dusts containing high amounts of $\mathrm{Zn}$ existing as $\mathrm{ZnFe}_{2} \mathrm{O}_{4}$ (Ndlovu, Simate, and Matinde, 2017; Lin et al., 2017). However, these processes are sensitive to economies of scale, have high thermal energy requirements, and require elaborate dust collection systems and additional steps to recover volatile metals from the flue gas (Ndlovu, Simate, and Matinde, 2017). As a result, the application of hydrometallurgical processes in the recovery of metals from metallurgical dusts is slowly gaining prominence due to their greater flexibility of operation and the required economies of scale. Hydrometallurgical processes also have lower capital costs and few or no environmental challenges associated with flue gases, dusts, and noise. Notwithstanding some of these advantages, the technical and economic feasibility of hydrometallurgical processes requires careful management of water, waste water, and process solutions (Palencia et al., 1999; de Buzin, Heck, and Vilela, 2017; Ndlovu, Simate, and Matinde, 2017). In addition, the widespread adoption of hydrometallurgical processes has largely been constrained by the complex physical, chemical, and mineralogical characteristics of the dust materials. For example, most of the zinc in typical EAF dusts occurs as franklinite $\left(\mathrm{ZnFe}_{2} \mathrm{O}_{4}\right)$, which is stable and insoluble in most acidic, alkaline, and chelating media under conventional conditions (Palencia et al., 1999; Miki et al., 2016; de Buzin, Heck, and Vilela, 2017; Ndlovu, Simate, and Matinde, 2017). Furthermore, hydrometallurgical processes using conventional leaching and chelating media also suffer from poor selectivity and codissolution, thereby increasing the complexity of downstream solution purification processes. As a result, several alternative leaching and pretreatment processes have been proposed, or are being investigated, in order to improve the kinetics and economics of the leaching processes (Leclerc, Meux, and Lecuire, 2002; Abott et al., 2006, 2009; Steer and Griffiths, 2013; Bakkar, 2014; Chairaksa-Fujimoto et al., 2015; Miki et al., 2016; Chairaksa-Fujimoto et al., 2016; Binnemans and Jones, 2017; Xing, Wang, and Chen, 2017).

\section{Emerging trends in the recycling and re-use of metallurgical dusts and other residues}

Pretreatment and leaching of ferrous dusts-As discussed in the preceding sections, the presence of the refractory $\mathrm{ZnFe}_{2} \mathrm{O}_{4}$ spinel presents challenges to the conventional leaching of these materials in aqueous media. As such, several studies have focused on the thermal pretreatment of Zn-bearing dusts before the leaching process (Chairaksa-Fujimoto et al., 2015; Miki et al., 2016; Chairaksa-Fujimoto et al., 2016; Yakornov et al., 2017). Chairaksa-Fujimoto et al. (2015) investigated the effect of $\mathrm{CaO}$ addition on the conversion of $\mathrm{ZnFe}_{2} \mathrm{O}_{4}$ in industrial EAF dust. Their findings confirmed that the $\mathrm{ZnFe}_{2} \mathrm{O}_{4}$ spinel can be decomposed by thermal treatment in the temperature range $900-1100^{\circ} \mathrm{C}$ and in the presence of a stoichiometric amount of reactive $\mathrm{CaO}$ to produce $\mathrm{ZnO}$ and $\mathrm{Ca}_{2} \mathrm{Fe}_{2} \mathrm{O}_{5}$, as shown in Equation [2] (Chairaksa-Fujimoto et al. (2015):

$$
\begin{aligned}
& \mathrm{ZnFe}_{2} \mathrm{O}_{4(s)}+2 \mathrm{CaO}_{(s)}=\mathrm{Ca}_{2} \mathrm{Fe}_{2} \mathrm{O}_{5(s)}+\mathrm{ZnO}_{(s)} \\
& \Delta G^{0}(\mathrm{~J} / \mathrm{mol})=32114+11.329 \mathrm{~T}+4.201 \times 10^{-3} \\
& T^{2}-5.46 \times 10^{5} T^{-2}-3.373 T \ln T=-41006.722 \mathrm{~J} / \mathrm{mol}
\end{aligned}
$$

Based on the thermodynamic feasibility of reaction [2] at the temperatures investigated, the authors have demonstrated that $100 \%$ of the $\mathrm{ZnO}$ can be selectively leached in conventional acidic or alkaline media after 4 hours, compared to $40 \%$ leaching efficiency in the case of the as-received sample (Chairaksa-Fujimoto et al., 2015, 2016).

\begin{tabular}{|c|c|c|}
\hline Process & Process description & Products \\
\hline $\begin{array}{l}\text { Rotary hearth furnace } \\
\text { (Zn-containing dusts), e.g. } \\
\text { FASTMET }^{\circledR}, \text { INMETCO }\end{array}$ & $\begin{array}{l}\text { Solid-state carbothermic reduction and de-zincification } \\
\text { of pelletized steelmaking dusts using rotary hearth furnaces } \\
\text { (RHFs) in the temperature range } 1200-1400^{\circ} \mathrm{C} \text {. } \\
\text { Secondary dust is processed to recover zinc. }\end{array}$ & $\begin{array}{l}\text { Crude } \mathrm{ZnO} \text {-rich off-gas and metallized direct reduced } \\
\text { iron. }\end{array}$ \\
\hline Premus ${ }^{\circledR}$ & $\begin{array}{l}\text { Multi-hearth furnace solid-state reduction (temperature } \\
\text { range } 1000-1100^{\circ} \mathrm{C} \text { ) of steelmaking dusts using coke or } \\
\text { coal fines and the EAF melting of the resulting hot } \\
\text { briquetted iron }(\mathrm{HBI}) \text {. }\end{array}$ & $\begin{array}{l}\text { Crude } \mathrm{ZnO} \text {-rich off gas ( } \mathrm{Zn}>55 \text { wt.\%), direct charging of } \\
\mathrm{HBI} \text { into EAF. }\end{array}$ \\
\hline Shaft furnace & $\begin{array}{l}\text { Coke packed-bed shaft furnace for smelting-reduction of } \\
\text { steelmaking dusts in the temperature range } 1500-1600^{\circ} \mathrm{C} \text {. }\end{array}$ & \multirow[t]{4}{*}{$\begin{array}{l}\text { Crude } \mathrm{ZnO} \text {-rich off-gas, hot metal/ crude steel, and } \\
\text { environmentally benign barren slag. }\end{array}$} \\
\hline Oxyfines $^{\text {TM }}$ & $\begin{array}{l}\text { Oxy-fuel process for smelting of fine dusts in the temperature } \\
\text { range } 1600-1700^{\circ} \mathrm{C} \text {. }\end{array}$ & \\
\hline Enviroplas $^{\mathrm{TM}}$ & $\begin{array}{l}\text { DC -arc plasma furnace for smelting-reduction of steelmaking } \\
\text { and ferroalloy fine dusts in the temperature range } 1600-1700^{\circ} \mathrm{C} \text {. }\end{array}$ & \\
\hline OxyCup ${ }^{\circledR}$ Process & $\begin{array}{l}\text { Shaft furnace for reduction and melting of agglomerated ferrous } \\
\text { metal dusts in the temperature range } 1500-1600^{\circ} \mathrm{C} \text {. }\end{array}$ & \\
\hline Waelz process & $\begin{array}{l}\text { Waelz kiln carbothermic reduction of pelletized metal oxides } \\
\left(1100-1200^{\circ} \mathrm{C}\right) \text {, volatilization of } \mathrm{Zn} \text { and } \mathrm{Pb} \text { compounds and } \\
\text { further processing of } \mathrm{ZnO} \text { - and } \mathrm{PbO} \text {-rich off-gas dust. }\end{array}$ & \\
\hline
\end{tabular}

Table IV

Summary of processes for metal recovery and recycling of ferrous metallurgical dusts 


\section{Mining and metallurgical wastes: a review of recycling and re-use practices}

Since the solubilities of iron and calcium were negligible under the experimental conditions investigated, the $\mathrm{Ca}_{2} \mathrm{Fe}_{2} \mathrm{O}_{5}$ residue can be used as a dephosphorization fluxing agent in the steelmaking process.

Application of solvometallurgy in the recovery of metals from secondary resources-In order to increase the leachability and selectivity, the use of non-aqueous solvents in the form of molecular organic solvents, ionic liquids, deep eutectic solvents, organic solvents, and supercritical carbon dioxide, among others, has been explored in detail (Leclerc, Meux, and Lecuire, 2002; Abbott et al., 2005, 2006, 2009, 2011; Nockemann et al., 2006, 2008; Steer and Griffiths, 2013; Kilicarslan et al., 2014, 2015; Kilicarslan and Saridede, 2015; Davris et al., 2016; Amarasekara, 2016; Wang et al., 2016a, 2016b; Abbott et al., 2006a, 2006b, 2009; Park et al., 2014; Binnemans and Jones, 2017). Of particular interest in recent years is the use of ionic liquids, in the form of protic ionic liquids and carboxyl acid group functionalized ionic liquids, in the leaching of metals from a variety of ores and secondary resources (Abbott et al., 2005; 2006a, 2006b, 2009, 2011; Kilicarslan et al., 2014; 2015; Kilicarslan and Saridede, 2015; Amarasekara, 2016; Wang et al., 2016a, 2016b; Park et al., 2014; Binnemans and Jones, 2017). Ionic liquids are low-temperature molten salts comprising cations and organic/inorganic anions, and are increasingly gaining traction due to their desired properties such as non-volatility, low toxicity, good ionic conductivity, and wide electrochemical potential window (Park et al., 2014).

Kilicarslan et al. (2014) investigated the use of 1-butyl3 -methyl-imidazolium hydrogen sulphate $\left(\mathrm{bmim}+\left(\mathrm{HSO}_{4}^{-}\right)\right)$ ionic liquid in the presence of hydrogen peroxide $\left(\mathrm{H}_{2} \mathrm{O}_{2}\right)$ and potassium peroxymonosulfate (oxone) as the oxidants for leaching brass wastes containing 3.4\% Al, 5.81\% Ca, 22\% $\mathrm{Cu}, 12.17 \% \mathrm{Si}$, and $53.92 \% \mathrm{Zn}$. The results show that 50 vol. $\%\left[\mathrm{bmim}^{+}\right] \mathrm{HSO}_{4}{ }^{-}$in aqueous media is an efficient ionic liquid for brass ash leaching, and resulted in dissolution efficiencies of $99 \%$ for $\mathrm{Zn}$ and $24.82 \%$ for $\mathrm{Cu}$, even without the use of any oxidant. Other studies also indicated that pure zinc in brass waste could be recovered by leaching in Bronsted acidic ionic liquid and electrowinning (Kilicarslan and Saridede, 2015; Amarasekara, 2016).

Due to their similar solvent properties to ionic liquids, the use of deep eutectic solvents has also gained appreciable attention in the dissolution of metals oxides from secondary resources (Abbott et al., 2005, 2006a, 2011). Abbott et al. (2005) investigated the solubility of various metal oxides using low-temperature choline chloride $\left(\mathrm{HOC}_{2} \mathrm{H}_{4} \mathrm{~N}(\mathrm{CH} 3)_{3}{ }^{+}\right.$ $\mathrm{Cl}-$ )-based deep eutectic solvents. Their findings, based on the solubility of metal oxides in 2:1 urea/choline chloride eutectic at $60^{\circ} \mathrm{C}$, indicated that oxides such as $\mathrm{ZnO}, \mathrm{PbO}_{2}$, and $\mathrm{Cu}_{2} \mathrm{O}$ exhibit appreciable solubility, whereas the solubility of iron and aluminium oxides is low (Table V). The selectivity of the chosen deep eutectic solvents indicates the potential to selectively leach and separate the metals from complex metallurgical dust mixtures using electrochemical methods (Abbott et al., 2005, 2006, 2011).

Although the commercial adoption of solvometallurgy processes is still in its infancy, these techniques provide several advantages such as high selectivity, ability to recover the valuable metals in their pure states, and the ability to detoxify and produce environmentally benign residues.
Table VI summarizes some of the research that has been, or is being, conducted using hydrothermal treatment and leaching of metallurgical dusts and residues in non-aqueous solvents in order to enhance the leachability of metallurgical dusts and residues.

Synthesis of structural and functional materials-To date, the recovery of metals from metallurgical dusts using conventional pyrometallurgical and hydrometallurgical approaches has been implemented with varying degrees of success. In parallel to the ongoing efforts to recover valuable metals using these processes, extensive research is also being conducted to increase the valorisation potential by incorporating these materials in the synthesis of structural and functional materials such as glasses, ceramics, and soft magnetic ferrites (Barbieri et al., 2002; Rashad, 2006; Machado et al., 2011; Vieira et al., 2013; Stathopoulos et al., 2013; Wang et al., 2017a; Salamati, Younesi, and Bahramifar, 2017; Chinnam et al., 2017). Most of these studies have demonstrated the potential to synthesize highvalue functional soft magnetic spinel ferrites $\left(\mathrm{MFe}_{2} \mathrm{O}_{4}\right.$, where $\mathrm{M}$ is $\mathrm{Ni}, \mathrm{Cr}, \mathrm{Zn}, \mathrm{Mn}$, etc.) from the solid-state reaction, sintering, hot pressing, and/or densification of metallurgical dusts containing these materials. For example, Wang et al. (2017a) proposed an innovative one-step process for the synthesis of $\mathrm{Ni}-\mathrm{Zn}$ spinel ferrites with high saturation magnetization $\left(M_{S}\right.$ approx. 60.5 emug-1) and low coercivity ( $H_{C}$ approx. $49.8 \mathrm{Oe}$ ) from the solid-state reaction of EAF dust with $\mathrm{NiCl}_{2} \cdot 6 \mathrm{H}_{2} \mathrm{O}$ at $1100^{\circ} \mathrm{C}$ for 2 hours. In other studies, Salamat, Younesi, and Bahramifar (2017) proposed a method to synthesize magnetic core-shell $\mathrm{Fe}_{3} \mathrm{O}_{4} @ \mathrm{TiO}_{2}$ nanocomposites from EAF dusts, with high degree of superparagnetism and photocatalytic activity for the decomposition of chemical oxygen demand (COD) in steel mill wastewater. The proposed processes practically demonstrated the potential to transform waste streams such as EAF dusts from problematic solid wastes to high-valueadded products (Vieira et al., 2013; Stathopoulos et al., 2013; Wang et al., 2017a; Chinnam et al., 2017; Salamati et al., 2017). Table VII highlights some of the innovative approaches currently being employed to increase the valorisation potential by incorporating these materials in the synthesis of structural and functional materials.

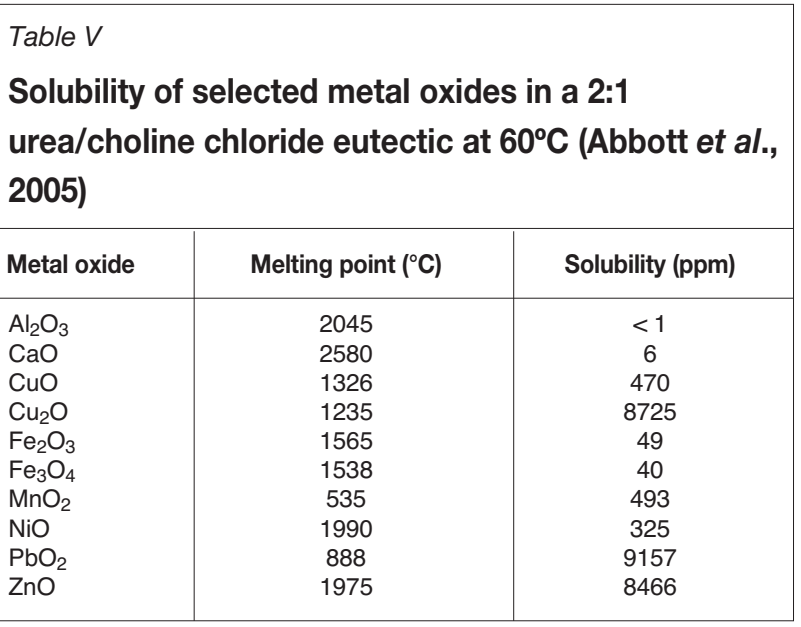




\section{Mining and metallurgical wastes: a review of recycling and re-use practices}

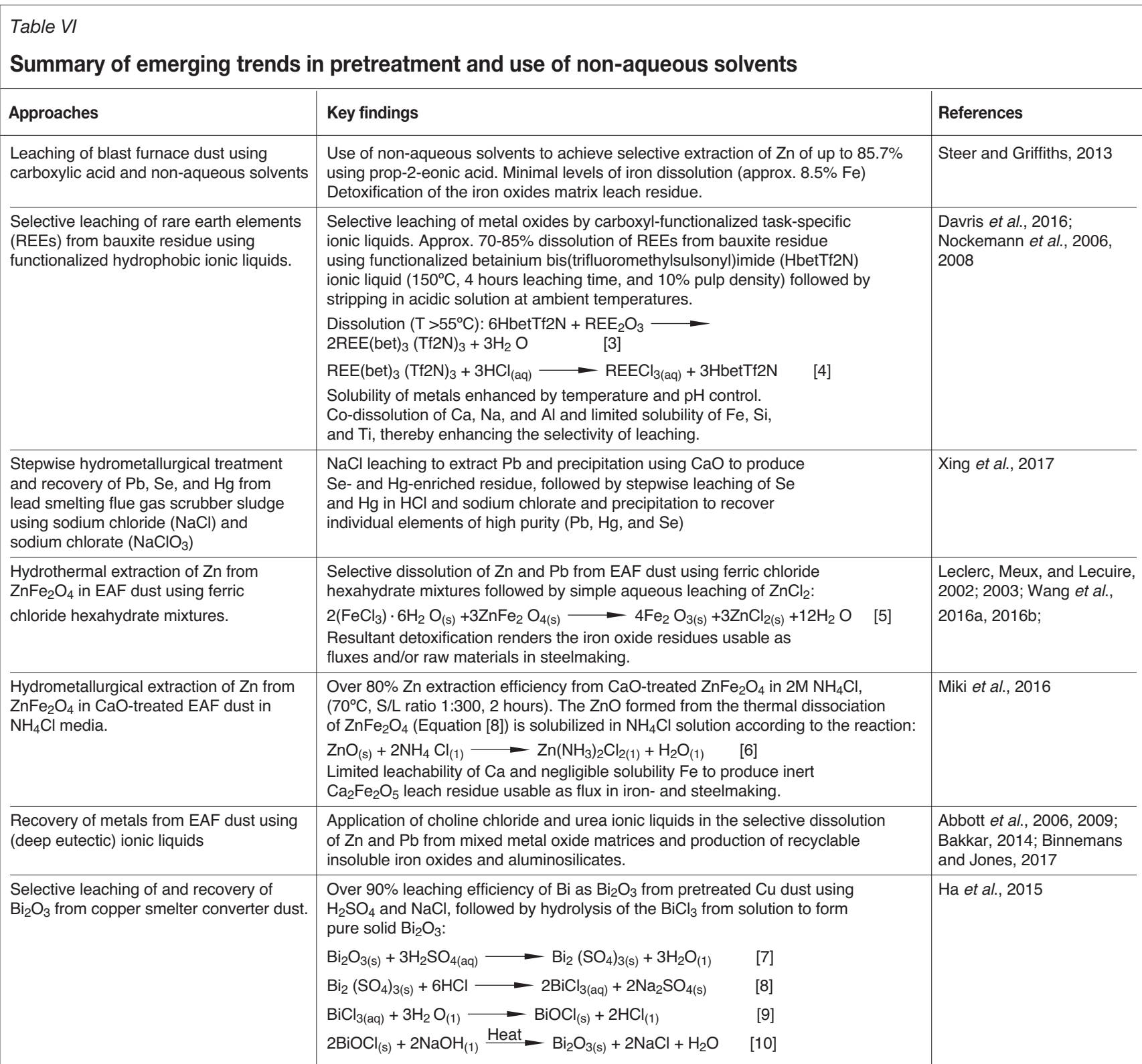

Metal recovery, recycling and re-use of metallurgical slags Metallurgical slags play indispensable roles in the efficient extraction of metals, and are produced in large volumes in pyrometallurgical smelting and refining processes (Pretorius and Nunnington, 2002; Reuter, Xiao, and Boin, 2004; Durinck et al., 2008). In fact, the solidified slag constitutes a high-volume by-product from most pyrometallurgical processes (Reuter, Xiao, and Boin, 2004; Durinck et al., 2008). During smelting and refining processes, slag separates from the metal/alloy and is tapped from the furnace before being granulated or slow-cooled. Depending on process design and conditions, solidified metallurgical slags contain significant amounts of entrained and/or dissolved metals, which can cause serious long-term environmental harm. For example, the presence of entrained and/or dissolved toxic metal species, such as chromium in stainless steel and ferrochromium alloy slags, can cause serious environmental problems due to the high leachability, mobility, and toxicity of the higher valence chromium $\mathrm{Cr}(\mathrm{VI})$ species (Durinck et al., 2008; Ndlovu, Simate, and Matinde, 2017). As a result, the current practice of disposing process slags in landfills presents environmental challenges, hence the need for protracted efforts to increase the recyclability and re-use potential of these materials (Ndlovu, Simate, and Matinde, 2017).

As indicated in Table VIII, there are several opportunities, as well as constraints, in the recycling and re-use of metallurgical slags. Nevertheless, the pyrometallurgical industry continues to explore opportunities in order to increase the valorisation potential of metallurgical slags. Several researchers have focused on the applications of metallurgical slags in other sectors of the economy (Reuter, Xiao, and Boin, 2004; Euroslag, 2017; Ndlovu, Simate, and Matinde, 2017). In particular, extensive research has been conducted on the application of the various types of process slags as construction materials (Euroslag, 2017; World Steel Association, 2015), in the manufacture of ceramics and other functional materials (Quijorna, Miguel, and Andres, 2011; 


\section{Mining and metallurgical wastes: a review of recycling and re-use practices}

Table VII

\section{Examples of ongoing research to increase the valorization potential of ferrous metallurgical dusts}

\begin{tabular}{|c|c|c|}
\hline Approaches & Comments & References \\
\hline $\begin{array}{l}\text { Thermal and chemical behaviour of } \\
\text { different glasses containing steel fly } \\
\text { ash and their transformation into } \\
\text { glass-ceramics }\end{array}$ & $\begin{array}{l}\text { Synthesis of chemically inert and coloured glasses from mixtures of } \\
\text { up to } 10 \text { wt.\% steel fly ash, } \mathrm{CaO}-\mathrm{MgO}-\mathrm{Al}_{2} \mathrm{O}_{3}-\mathrm{SiO}_{2} \text { glass-ceramic systems, } \\
\text { and other kinds of inorganic matrices. }\end{array}$ & $\begin{array}{l}\text { Barbieri, Corradi, } \\
\text { and Lancellotti } 2002\end{array}$ \\
\hline $\begin{array}{l}\text { Stabilization of nickel constituents of } \\
\text { dusts in aluminate and ferrite spinels } \\
\text { and investigating their leaching behavior. }\end{array}$ & $\begin{array}{l}\text { Sintering }\left(600-1480^{\circ} \mathrm{C} ; 3 \text { hours) of nickel-laden waste sludge to bind the nickel }\right. \\
\text { in nickel aluminate }\left(\mathrm{NiAl}_{2} \mathrm{O}_{4}\right) \text { and nickel ferrite }\left(\mathrm{NiFe}_{2} \mathrm{O}_{4}\right) \text { stable spinel phases } \\
\text { with low toxicity characteristic leaching properties (TCLPs). }\end{array}$ & $\begin{array}{l}\text { Shih, White, and Leckie, } \\
2006\end{array}$ \\
\hline $\begin{array}{l}\text { Synthesis and magnetic properties of } \\
\text { manganese ferrite from low-grade } \\
\text { smanganese ore }\end{array}$ & $\begin{array}{l}\text { Synthesis of manganese ferrite with magnetic properties }\left(M_{s} \text { approx. }\right. \\
\left.27.24 \text { emug }^{-1}\right) \text { from low-grade } M n \text { ore using oxidative acid leaching, co- } \\
\text { precipitation, and calcination }\left(1000-1200^{\circ} \mathrm{C}\right) \text {. }\end{array}$ & Rashad, 2006 \\
\hline $\begin{array}{l}\text { Structural ceramics made with clay and } \\
\text { steel dust pollutants }\end{array}$ & $\begin{array}{l}\text { Synthesis of brick and hollow brick materials meeting TCLPs standards from } \\
\text { sintering clay blends containing up to } 20 \mathrm{wt} . \% \text { EAF dust at } 1100^{\circ} \mathrm{C} \text {. }\end{array}$ & Machado et al., 2011 \\
\hline Structural ceramics containing EAF dust & $\begin{array}{l}\text { Pilot-scale study of the stabilization properties of EAF dust/clay ceramic structures } \\
\text { and the synthesis of structural ceramic blocks containing up to } 5 \mathrm{wt} \% \text { EAF dust } \\
\text { with good chemical, macroscopic, and mechanical properties and low TCLPs. }\end{array}$ & Stathopoulos et al., 2013 \\
\hline Recycling of EAF dust into red mud & $\begin{array}{l}\text { Synthesis of fired ceramics from mixtures of EAF dust and natural clays with } \\
\text { desirable mineralogical and physico-mechanical properties for civil } \\
\text { construction applications. }\end{array}$ & Vieira et al., 2013 \\
\hline $\begin{array}{l}\text { Synthesis of magnetic core-shell } \\
\mathrm{Fe}_{3} \mathrm{O}_{4} @ \mathrm{TiO}_{2} \text { nanoparticles from } \\
\text { EA dust }\end{array}$ & $\begin{array}{l}\text { Synthesis of magnetic core-shell } \mathrm{Fe}_{3} \mathrm{O}_{4} @ \mathrm{TiO}_{2} \text { nanocomposites from } \mathrm{EAF} \text { dust } \\
\text { with high degree of superparagnetism and photocatalytic activity for the } \\
\text { decomposition of chemical oxygen demand }(\mathrm{COD}) \text { in steel mill wastewater. }\end{array}$ & Salamati et al., 2017 \\
\hline $\begin{array}{l}\text { Functional glasses and glass-ceramics } \\
\text { from iron-rich waste and industrial } \\
\text { residues }\end{array}$ & $\begin{array}{l}\text { Review of processes and technologies for the synthesis of functional glass-based } \\
\text { products with suitable catalytic activity, magnetic, optical, and electrical properties } \\
\text { from iron-oxide-containing residues. }\end{array}$ & Chinnam et al., 2017 \\
\hline $\begin{array}{l}\text { Facile synthesis of metal-doped } \mathrm{Ni}-\mathrm{Zn} \\
\text { ferrite from treated } \mathrm{Zn} \text {-containing } \\
\text { EAF dust }\end{array}$ & $\begin{array}{l}\text { One-step process for the synthesis of } \mathrm{Ni}-\mathrm{Zn} \text { spinel ferrites with high saturation } \\
\text { magnetization }\left(M_{s} \text { approx. } 60.5 \mathrm{emug}^{-1}\right) \text { and low coercivity }\left(H_{c} \text { approx. } 49.8 \mathrm{Oe}\right) \\
\text { from the solid-state reaction of EAF dust with } \mathrm{NiCl}_{2} \cdot 6 \mathrm{H}_{2} \mathrm{O} \text { at } 1100^{\circ} \mathrm{C} \text { for } 2 \text { hours. }\end{array}$ & Wang et al., 2017a \\
\hline
\end{tabular}

Table VIII

Properties, recycling, and re-use opportunities of selected metallurgical slags

\begin{tabular}{|c|c|c|}
\hline Category & Typical mineralogical composition & Recycling and re-use opportunities \\
\hline Blast furnace slags & $\begin{array}{l}\mathrm{CaO}-\mathrm{MgO}-\mathrm{Al}_{2} \mathrm{O}_{3}-\mathrm{SiO}_{2} \text { system. Crystallized mineral composition } \\
\text { consisting mainly of melilite }\left(\mathrm{Ca}_{2} \mathrm{MgSi}_{2} \mathrm{O}_{7}-\mathrm{Ca}_{2} \mathrm{Al}_{2} \mathrm{SiO}_{7}\right) \text {, } \\
\text { and merwinite }\left(\mathrm{Ca}_{3} \mathrm{MgSi}_{2} \mathrm{O}_{8}\right)\end{array}$ & $\begin{array}{l}\text { Granulated and used as additives in Portland cement, } \\
\text { geopolymers, and other absorbents. Slow-cooled } \\
\text { and used as and construction and soil aggregates. }\end{array}$ \\
\hline EAF slags & $\begin{array}{l}\mathrm{Ca}_{3} \mathrm{Mg}\left(\mathrm{SiO}_{4}\right)_{2} ; \beta-\mathrm{Ca}_{2} \mathrm{SiO}_{4} ;(\mathrm{Mg}, \mathrm{Mn})(\mathrm{Cr}, \mathrm{Al}, \mathrm{Fe})_{2} \mathrm{O}_{4} \text { spinel solid } \\
\text { solution; } \mathrm{CaAl}_{2} \mathrm{SiO}_{6} ;(\mathrm{Fe}, \mathrm{Mg}, \mathrm{Mn}) \mathrm{O} \text { wüstite-type solid solution; } \\
\mathrm{Ca}_{2}(\mathrm{Al}, \mathrm{Fe})_{2} \mathrm{O}_{5}\end{array}$ & \multirow{3}{*}{$\begin{array}{l}\text { Dissolved and/or entrained alloying elements. High level of } \\
\text { impurities for refining slags. Recycled as pre-melted fluxes. } \\
\text { Metal recovery and slag cleaning processes. Presence of } \\
\text { elevated amounts of toxic alloying elements, e.g. Cr and Ni, } \\
\text { limits their direct uptake in other sectors. }\end{array}$} \\
\hline Steelmaking slags & $\begin{array}{l}\mathrm{Ca}_{3} \mathrm{SiO}_{5} ; \alpha-\mathrm{Ca}_{2} \mathrm{SiO}_{4} ; \mathrm{Ca}_{2} \mathrm{Fe}_{2} \mathrm{O}_{5} ; \beta-\mathrm{Ca}_{2} \mathrm{SiO}_{4} ; \mathrm{FeO}-\mathrm{MnO}-\mathrm{MgO} \\
\text { solid solution; } \mathrm{MgO} \text {; wüstite solid solution. }\end{array}$ & \\
\hline $\begin{array}{l}\text { Stainless steel (AOD) } \\
\text { slags }\end{array}$ & $\begin{array}{l}\mathrm{FeCr}_{2} \mathrm{O}_{4} ; \mathrm{FeFe}_{2} \mathrm{O}_{4} ; \mathrm{Ni}-\mathrm{Cr}-\mathrm{Fe} \text { solid solution; } \mathrm{Ca}_{2} \mathrm{SiO}_{4} ; \mathrm{CaF}_{2} ; \\
\mathrm{Ca}_{14} \mathrm{Mg}_{2}\left(\mathrm{SiO}_{4}\right)_{8} ; \mathrm{Ca}_{2} \mathrm{SiO}_{4} ; \mathrm{Ca}_{4} \mathrm{Si}_{2} \mathrm{O}_{7} \mathrm{~F}_{2} ; \mathrm{MgO} ; \mathrm{Fe}-\mathrm{Cr} \text { alloy; } \\
\mathrm{Fe}-\mathrm{Ni} \text { alloy }\end{array}$ & \\
\hline $\begin{array}{l}\text { PGM smelting and } \\
\text { converting slags }\end{array}$ & $\begin{array}{l}\text { Fayalitic }\left(2 \mathrm{FeO} \cdot \mathrm{SiO}_{2}\right) \text { slags with some dissolved magnetite. } \\
\left.\text { Chromium present as spinels }(\mathrm{Fe}, \mathrm{Mg}) \mathrm{Cr}_{2} \mathrm{O}_{4}\right) \text {, particularly in } \\
\text { furnaces smelting UG2 concentrates. }\end{array}$ & $\begin{array}{l}\text { Slag cleaning and metal recovery. In-process build-up of } \\
\left.\mathrm{Cr}_{2} \mathrm{O}_{3} \text { as spinels }(\mathrm{Fe}, \mathrm{Mg}) \mathrm{Cr}_{2} \mathrm{O}_{4}\right) \text { in UG2 concentrates limits } \\
\text { recyclability and re-use. }\end{array}$ \\
\hline $\begin{array}{l}\text { Base metal slags } \\
\text { (copper and nickel) }\end{array}$ & $\begin{array}{l}\text { Fayalitic }\left(2 \mathrm{FeO} \cdot \mathrm{SiO}_{2}\right) \text { and } \mathrm{FeO}-\mathrm{CaO}-\mathrm{SiO}_{2} \text { slag systems } \\
\text { with some dissolved magnetite. }\end{array}$ & $\begin{array}{l}\text { Slag cleaning and metal recovery. Converter slag recyclable } \\
\text { as pre-melted fluxes. }\end{array}$ \\
\hline Ferroalloy slags & $\begin{array}{l}\mathrm{HCFeCr} \text { slags: } \mathrm{Al}_{2} \mathrm{O}_{3}-\mathrm{MgO}-\mathrm{SiO}_{2}-\mathrm{Cr}_{2} \mathrm{O}_{3} \text { system containing } \\
\text { various phases such as } \mathrm{MgO}-\mathrm{MgO} \cdot \mathrm{Al}_{2} \mathrm{O}_{3}-2 \mathrm{MgO} \cdot \mathrm{SiO}_{2}-2 \mathrm{CaO} \text {. } \\
\mathrm{SiO}_{2}, \mathrm{MgO} \cdot \mathrm{Cr}_{2} \mathrm{O}_{3},\left(\mathrm{Mg}_{2}(\mathrm{Cr}, \mathrm{Al}, \mathrm{Si})_{2} \mathrm{O}_{6}\right.\end{array}$ & $\begin{array}{l}\text { Slag cleaning and metal recovery. High leachability, mobility, } \\
\text { and toxicity potential of entrained and/or dissolved } \mathrm{Cr}(\mathrm{VI}) \\
\text { species limit the alternative applications. }\end{array}$ \\
\hline
\end{tabular}

Ponsot and Bernado, 2013; Karayannis et al., 2017), and as geopolymeric materials (Kalinkin et al., 2014; Huang et al., 2015). However, the presence of entrained and/or dissolved toxic metal elements, as well as the build-up of deleterious elements in the slag, is still a major constraint in the recycling and re-use of these materials.

\section{Emerging trends in the recycling and re-use of} metallurgical slags

In the past, research in pyrometallurgy focused mostly on improving process performance by optimizing the properties of slags (Mills, Yuan, and Jones, 2011), but largely ignored 


\section{Mining and metallurgical wastes: a review of recycling and re-use practices}

their environmental efficacy once the slags were tapped from the furnace. In other words, not much emphasis was placed on the holistic integration between the required properties of slags for process performance and their environmental performance after solidification and disposal. However, the drive for sustainability and environmental stewardship mandates the need to take into account the environmental effects of the slags. To date, emerging research in the pyrometallurgical industry is shifting towards both the inprocess and post-process engineering of slag properties in order to achieve metallurgical and energy efficiency in the furnace while producing an environmentally benign slag.

Engineered slag structure-process-properties for recycling and environmental performance-The stabilization of dissolved and/or entrained toxic metal species in stable phases in various slags has drawn considerable attention in recent years (Barbieri et al., 1994; Kühn and Mudersbach, 2004; Tanskannen and Makkonen, 2006; Durinck et al., 2008a, 2008b; Albertsson, Teng, and Björkman, 2014; Santos et al., 2012; Albertsson, 2013; Cabrera-Real et al., 2012; Liapis and Papayiani, 2015; Piatak, Parsons, and Seal, 2015). In particular, Kühn and Mudersbach (2004) investigated the effect of $\mathrm{MgO}, \mathrm{Al}_{2} \mathrm{O}_{3}$, and $\mathrm{FeO}$ additions to high-temperature slags. Their findings indicate that the addition of these compounds prior to the crystallization of high-temperature slags decreased the leachability of chromium species from the solidified slags. Cabrera-Real et al. (2012) investigated the effect of basicity $\left(\mathrm{CaO} / \mathrm{SiO}_{2}\right)$ and $\mathrm{MgO}$ on the stability of the mineralogical phases formed during crystallization of $\mathrm{CaO}-\mathrm{SiO}_{2}-\mathrm{Cr}_{2} \mathrm{O}_{3}-\mathrm{CaF}_{2}-\mathrm{MgO}$ slags. Mineralogical characterization of the solidified slag highlighted the predominance of $\mathrm{MgCr}_{2} \mathrm{O}_{4}$ spinels, and minor presence of $\mathrm{CaCr}_{2} \mathrm{O}_{4}$ and $\mathrm{CaCr}_{2} \mathrm{O}_{4}$ phases at $\mathrm{CaO} / \mathrm{SiO}_{2}=1$. Increasing the $\mathrm{CaO} / \mathrm{SiO}_{2}$ ratio to 2 resulted in the predominance of $\mathrm{MgCr}_{2} \mathrm{O}_{4}, \mathrm{CaCr}_{2} \mathrm{O}_{4}$, and the $\mathrm{Cr}(\mathrm{V})$ containing complex $\mathrm{Ca}_{5}\left(\mathrm{CrO}_{4}\right)_{3} \mathrm{~F}$ (Cabrera-Real et al., 2012). Based on the comparative TCLPs of chromium from the different phases, the findings indicated the highest leachability of $\mathrm{Cr}$ at $\mathrm{CaO} / \mathrm{SiO}_{2}=2$, owing to the presence of potentially soluble $\mathrm{CaCr}_{2} \mathrm{O}_{4}$ and $\mathrm{Ca} 5\left(\mathrm{CrO}_{4}\right)_{3} \mathrm{~F}$ phases. The low leachability of $\mathrm{MgO}$-stabilized slag phases was attributed to the predominance of $\mathrm{MgCr}_{2} \mathrm{O}_{4}$ spinel phases, which in essence, function to bind the $\mathrm{Cr}$ in a stable spinel (CabreraReal et al., 2012). The effect of basicity on the stabilization of chromium species in stable phases was also investigated by Albertsson (2013). Based on high-temperature engineered parameters such as alumina addition, heat treatment, and oxygen partial pressure, Albertsson (2013) proposed that the addition of alumina to molten slags was effective in binding the chromium in the $\mathrm{MgAl}_{2} \mathrm{O}_{4}-\mathrm{MgCr}_{2} \mathrm{O}_{4}$ stable spinel phases. Slow soaking of solidified slag at low temperatures and low oxygen partial pressure also improved the formation of the spinel phases and reduced the amount of chromium dissolved in water-soluble matrix phases. Conversely, the heat treatment of slags with $\mathrm{CaO} / \mathrm{SiO}_{2}$ ratio greater than 1.4 under high oxygen potential accentuated the formation of leachable Cr-bearing phases (Albertsson, 2013).

In earlier studies, Barbieri et al. (1994) investigated the solubility, reactivity and nucleation of $\mathrm{Cr}_{2} \mathrm{O}_{3}$ in a CaO-MgO$\mathrm{Al}_{2} \mathrm{O}_{3}-\mathrm{SiO}_{2}$ glassy system. The slag system, containing up to $5 \mathrm{~mol} \% \mathrm{Cr}_{2} \mathrm{O}_{3}$, was melted at $1400^{\circ} \mathrm{C}$ and the effect of $\mathrm{Mg}$ content on the spinel formation was investigated. At the glass melting temperature, the reaction of $\mathrm{Cr}_{2} \mathrm{O}_{3}$ and $\mathrm{MgO}$ was proposed to proceed to form stable $\mathrm{Mg}_{2} \mathrm{Cr}_{2} \mathrm{O}_{4}$ spinels (Barbieri et al., 1994). Tanskanen and Makkonen (2006) also investigated the mineralogical and petrological characteristics of $\mathrm{CaO}-\mathrm{SiO}_{2}-\mathrm{Al}_{2} \mathrm{O}_{3}-\mathrm{MgO}-\mathrm{Fe}-\mathrm{Cr}$ slags from high-carbon ferrochrome production. Their findings indicated that the slag solidified with a partly crystalline and porphyritic structure with hypidiomorphic spinel $\left((\mathrm{Mg}, \mathrm{Fe})(\mathrm{Fe}, \mathrm{Al}, \mathrm{Cr})_{2} \mathrm{O}_{4}\right)$ crystals enclosed in a homogenous glass matrix, as shown in Figure 1.

In line with the structure-process-property hypotheses, Durinck et al. (2008a, 2008b) investigated the hot stage processing of molten steelmaking slags in order to enhance the environmental performance of the solidified slags. Based on case studies on $2 \mathrm{CaO} \cdot \mathrm{SiO}_{2}\left(\mathrm{C}_{2} \mathrm{~S}\right)$-driven disintegration and chromium leaching, Durinck et al. (2008a) proposed that the functional properties of solidified slags can be significantly enhanced by controlled additions to the high-temperature slags and/or by variations in the cooling path. In other studies, Liapis and Papayianni (2015) investigated the high-

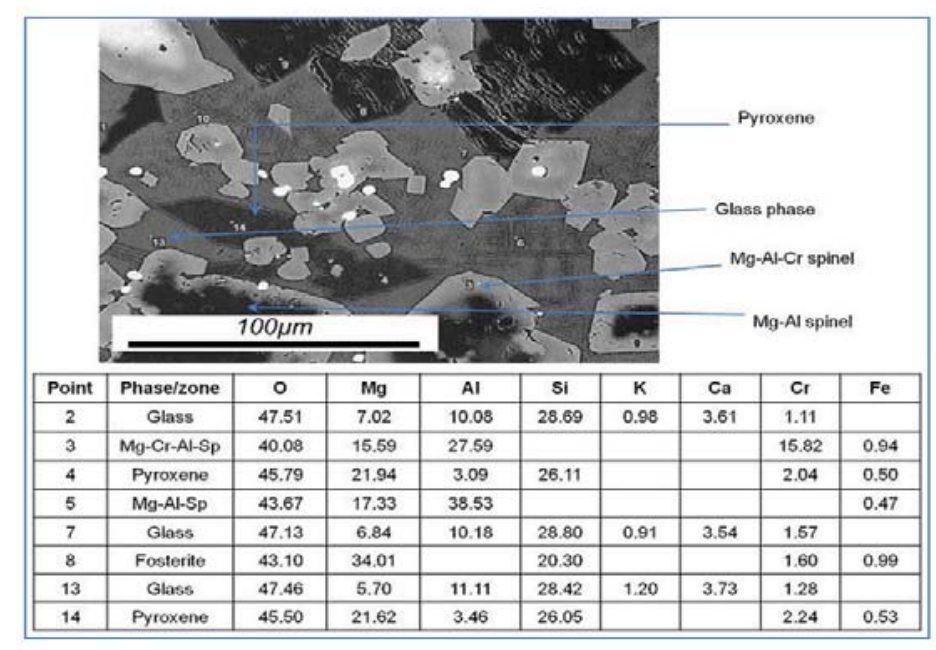

Figure 1-Phase composition and mineralogy of air-cooled ferrochromium slags (Tanskanen and Makonnen, 2006; Ndlovu et al., 2017) 


\section{Mining and metallurgical wastes: a review of recycling and re-use practices}

temperature in-process modification of high-carbon EAF slags using perlite (with non-normalized composition 76 wt. $\% \mathrm{SiO}_{2}-14$ wt. $\% \mathrm{Al}_{2} \mathrm{O}_{3}-3.4$ wt. $\% \mathrm{Na}_{2} \mathrm{O}-2.7$ wt. $\% \mathrm{~K}_{2} \mathrm{O}$ 1.2 wt.\% $\mathrm{CaO}-1 \mathrm{wt} . \% \mathrm{FeO}_{\mathrm{x}}$ ), ladle furnace slags (with nonnormalized composition approximately $62 \mathrm{wt} . \% \mathrm{CaO}-14.5$ wt.\% $\mathrm{SiO}_{2}-3.6$ wt.\% MgO-2.5 wt.\% $\mathrm{FeO}_{\mathrm{x}}-2$ wt. $\% \mathrm{Al}_{2} \mathrm{O}_{3}$ ) and olivine (with non-normalized composition approximately 50 wt. $\%$ MgO-36 wt.\% $\mathrm{SiO}_{2}-8.7$ wt.\% $\mathrm{FeO}_{\mathrm{x}}-1.2$ wt.\% $\left.\mathrm{CaO}\right)$ additives. Based on tailored chemical and mineralogical compositions, the modified EAF slag was found to be suitable for use in the production of normal weight cement concrete. Interestingly, the addition of slag modifiers had minimal interference on the process performance of the EAF (Liapis and Papayianni, 2015).

The studies highlighted so far support the hypothesis that the physicochemical properties of slag in the molten state can be engineered in order to obtain the desired solidified and crystal structure properties that are essential for improving the recycling and environmental attributes of metallurgical slags. In essence, the domain of slag engineering is a promising approach to controlling the solidification and crystallization properties of slags in order to improve their environmental compatibility. Slag engineering can improve the environmental performance of slags through binding the toxic metal species in stable spinel phases. In short, the objectives of slag engineering can be achieved by integrating the following aspects: (1) the post-tapping processing, solidification, and crystallization pathways, mineralogy, and speciation of entrained alloys in the slag, (2) evaluation of the efficacy of the proposed post-treatment methods based on TLCPs of the disposable and/or re-usable slag materials, and (3) correlating the structure, process and properties of slags to the broad recyclability and environmental performance.

Engineered structure-process-properties offerrous slags for metal recovery_-Inasmuch as slag cleaning using pyrometallurgical furnaces was the major focus to recover entrained and/or dissolved metals from slag, attention in recent years has shifted towards the recovery of metals from solidified slags by physical beneficiation methods. As discussed earlier, the engineered solidification and crystallization behavior of slags can result in the evolution of certain phases with desired properties that are essential for the recovery of metals from these materials. This means the speciation behaviour of alloys in discrete phases in rapidly cooled slags can be exploited in the physical beneficiation of these slag materials (Engström et al., 2010; Burja et al., 2017). In fact, the recovery of dissolved and/or entrained metals and alloys can be enhanced by hot-stage engineering of the microstructural properties of slag materials during crystallization and solidification (Durinck et al., 2008a, 2008b; Liapis and Papayianni, 2015). This approach is based on the hypothesis that certain phases with desired properties in solidified slags can be engineered and maintained during the solidification process in order to facilitate their separation from the solidified slag. Based on studies of the crystallization behaviour of steelmaking slags during rapid cooling, Engström et al. (2010) observed the formation of wüstite-type solid solution ( $\mathrm{Mg}, \mathrm{Fe}, \mathrm{Mn}) \mathrm{O}$ enclosed in $\beta$ $\mathrm{Ca}_{2} \mathrm{SiO}_{4}$ phases. Burja et al. (2017) investigated the speciation of chromium in rapidly cooled $\mathrm{CaO}-\mathrm{SiO}_{2}-\mathrm{Cr}_{2} \mathrm{O}_{3}$ and $\mathrm{CaO}-\mathrm{SiO}_{2}-\mathrm{MgO}-\mathrm{Al}_{2} \mathrm{O}_{3}-\mathrm{Cr}_{2} \mathrm{O}_{3}$ stainless steel slags. Based on
X-ray diffraction analyses, the authors confirmed the presence of metallic $\mathrm{Cr}$ and $\mathrm{FeCr}$ phases, as well as the presence of calcium chromates, pseudowollastonite $\left(\mathrm{CaSiO}_{3}\right)$, and larnite $\left(\mathrm{Ca}_{2} \mathrm{SiO}_{4}\right)$ (Burja et al., 2017). The formation of metallic $\mathrm{Cr}$ and $\mathrm{FeCr}$ phases was particularly observed in lowbasicity slags containing high $\mathrm{CrO}_{\mathrm{x}}$ levels (Burja et al., 2017). In other studies, Norval and Oberholster (2011) investigated the effect of granulation on the recovery of manganese from re-melted FeMn slags. Their findings indicate a significant difference in the residual $\mathrm{MnO}$ content of granulated and aircooled slags, wherein the MnO content decreased to $6.1 \%$ in granulated slags compared with $21.8 \%$ in the air-cooled slags.

The formation in slags of certain phases with high magnetic susceptibilities can be engineered using postfurnace solidification processing, and such phases can be maintained during solidification to facilitate the separation of the alloys from solidified slag by magnetic separation. Based on the knowledge of soft magnetic properties of spinel ferrites synthesied by various methods (Viart et al., 2000; Sugimoto, 1999; Lakshmi, Kumar, and Thyagarajan, 2016; Zhang et al., 2016), the magnetic ferrite phases $\left(\mathrm{MFe}_{2} \mathrm{O}_{4}\right.$, where $\mathrm{M}$ is $\mathrm{Mn}, \mathrm{Ni}, \mathrm{Cr}, \mathrm{Mo}$, etc.) in crystallized slags can be exploited in the magnetic separation from the bulk nonmagnetic components (Semykina and Seetharaman, 2011; Semykina, 2013; Shatokha et al., 2013; Sharma, Sharma, and Shah, 2014; Menad, Kanari, and Save, 2014; Ma and Houser, 2014; Li et al., 2015; Lakshmi, Kumar, and Thyagarajan, 2016; Zhang et al., 2016; Jiang et al., 2018). In other words, the transformation of nonmagnetic compounds of transition metals in slags to ferrites with high magnetic susceptibilities by controlled solidification and crystallization of molten slags is a promising method to increase the recovery of values from steelmaking slags.

As highlighted earlier, certain phases, such as $\mathrm{MnFe}_{2} \mathrm{O}_{4}$ and $(\mathrm{Mg}, \mathrm{Fe}, \mathrm{Mn}) \mathrm{O}$, in crystallized slags possess magnetic properties that can potentially be exploited in their magnetic separation from the bulk non-magnetic components of steelmaking slags (Semykina and Seetharaman, 2011; Semykina, 2013; Shatokha et al., 2013; Menad, Kanari, and Save, 2014; Ma and Houser, 2014; Jian et al., 2017). Semykina (2013) proposed a slag utilization technique that involves the ambient air oxidation of molten $\mathrm{CaO}-\mathrm{FeO}-\mathrm{SiO}_{2}$ and $\mathrm{CaO}-\mathrm{FeO}-\mathrm{SiO}_{2}-\mathrm{MnO}-\mathrm{Cr}_{2} \mathrm{O}_{3}$ slags in order to precipitate ferrite phases that can then be recovered by magnetic separation. The proposed oxidation reactions are shown in Equations [11]-[13] (Semykina, 2013):

$$
\begin{aligned}
& 2(\mathrm{FeO})_{\text {slag }}+\mathrm{MnO}_{(\text {slag })}+\frac{1}{2} \mathrm{O}_{2(\text { air })} \rightarrow \mathrm{MnFe}_{2} \mathrm{O}_{4(s)} \\
& 3(\mathrm{FeO})_{\text {slag }}+\frac{1}{2} \mathrm{O}_{2(\text { air })} \rightarrow \mathrm{Fe}_{3} \mathrm{O}_{4(\text { s })} \\
& \mathrm{FeO}_{\text {slag }}+2 \mathrm{CrO}_{(\text {slag })}+\frac{1}{2} \mathrm{O}_{2(\text { air })} \rightarrow \mathrm{FeCr}_{2} \mathrm{O}_{4(s)}
\end{aligned}
$$

Based on the thermodynamic possibility of phase transformations in liquid slags highlighted in Equations [11]-[13], Shatokha et al., (2013) also investigated the selective recovery of iron and manganese values from oxidized $\mathrm{CaO}-\mathrm{SiO}_{2}-\mathrm{FeO}$ and $\mathrm{CaO}-\mathrm{SiO}_{2}-\mathrm{FeO}-\mathrm{MnO}$ slags. In recent studies, Jiang et al. (2018) investigated the oxidation behaviour of $\mathrm{BOF}$ slag $\left(\mathrm{CaO}-\mathrm{SiO}_{2}-\mathrm{MgO}\right.$ containing 10 


\section{Mining and metallurgical wastes: a review of recycling and re-use practices}

$\left.35 \mathrm{wt} . \% \mathrm{FeO}_{\mathrm{x}}\right)$ under ambient air and selected temperature $\left(1000-1100^{\circ} \mathrm{C}\right)$ conditions. Their findings also proved the potential to form magnetic spinel phases, in the form of magnetite $\left(\mathrm{Fe}_{3} \mathrm{O}_{4}\right)$ and magnesio-ferrite $\left(\mathrm{MgFe}_{2} \mathrm{O}_{4}\right)$, from the Fe-containing species in the slag. The studies highlighted so far substantiate the underlying hypotheses that the stable transition metal ferrites produced in liquid slag during solidification are amenable to separation from the bulk of the solidified slag by magnetic separation (Semykina and Seetharamn, 2011; Shatokha et al., 2013; Semykina, 2013; Jiang et al., 2018).

Recovery of sensible energy in molten slags-The pyrometallurgical extraction of metals is associated with high energy consumption. For example, the iron and steel manufacturing industry is one of the most energy-intensive industries, accounting for about 5-6\% of global energy consumption (Duan et al., 2017). According to Barat et al. (2011), the energy consumption in high-temperature metal extraction processes is distributed between metal, slag, offgas, and environmental losses. Depending on the slag/metal ratio and tapping temperatures, the slag thermal requirements in these processes can vary from $10-90 \%$ of the output energy (Barati, Esfahani, and Utigard, 2011). Due to the high volumes of iron and steel production, the production of ferrous metals accounts for over $90 \%$ of the available energy associated with slags. Slags also account for a significant amount of energy output from the energyintensive production processes of ferroalloys and other commodities. Barati, Esfahani, and Utigard (2011) summarized the historical global production of selected metallurgical slags, and the estimated energy content associated with these materials (Table IX).

Since the molten slags are tapped from smelting and refining furnaces at high temperatures, they contain a lot of sensible energy that can be harnessed. In order to increase sustainability in the high-temperature extraction of metals, several researchers have focused on the recovery of energy from the dry granulation of these molten materials (Bisio, 1997; Barati, Esfahani, and Utigard, 2011; Zhang et al., 2013; Liu et al., 2015, 2016; Rycroft, 2014). To date, several energy recovery processes have been investigated and developed, based primarily on the physical and chemical processing of these materials. Typical physical energy recovery processes include (Bisio, 1997; Rycroft, 2014; Barati, Esfahani, and Utigard, 2011):
(1) Dry granulation processes, wherein liquid slag is continuously broken down into droplets and the heat is recovered, firstly by the solidification of the droplets passing through a dry cooling stage, followed by the further recovery from the solid granules as they cool to ambient temperatures.

(2) Granulation by air blast, where a stream of liquid is broken down into droplets by high-pressure air jets. The air granulation process allows for the concomitant rapid cooling of slag and heat recovery from the air blast via a heat exchanger.

(3) Granulation by solid slag impingement, where the liquid stream is broken up into particles by a stream of recycled solid slag particles, and the energy is transferred to air for steam generation by convection in a multi-step fluidized bed.

(4) Centrifugal granulation, encompassing processes such as the rotating drum process, rotary cup atomizer, spinning disc atomizer, and rotating cylinder atomizer. The processes highlighted so far integrate the physical phenomena of slag solidification using centrifugal force or impinging jets, and heat transfer using media such air and steam in fluidized bed and/or countercurrent heat exchangers.

Extensive research has also been conducted on the recovery of sensible energy in liquid slags using chemical methods (Maruoka et al., 2004; Purwanto and Akiyama, 2004; Barati, Esfahani, and Utigard, 2011; Duan et al., 2014a, 2014b; Sun et al., 2015a, 2015b, 2016b; Duan, Yu, and Wang, 2017; Sun et al., 2017). Several researchers have proposed the use of molten slags in the gasification of coal and biomass to produce synthetic fuels and/or using the waste heat in liquid slags in methane-steam reforming reactions. In this case, it is proposed that the hot slag not only acts as a thermal medium but also as a catalyst for the gasification and reforming reactions. Using blast furnace slag waste heat as a thermal agent, Duan et al. (2014a) developed a technological and exergy analysis model based on gasifier system using coal/waste gas gasification. The findings indicated a recovery efficiency of $85 \%$ for the blast furnace slag waste heat, and an $80 \%$ conversion of the $\mathrm{CO}_{2}$ to syngas in the waste gas. In similar studies, Duan et al. (2014b) conducted a thermodynamic analysis of steam gasification of coal to produce hydrogen-rich gas using blast furnace slags

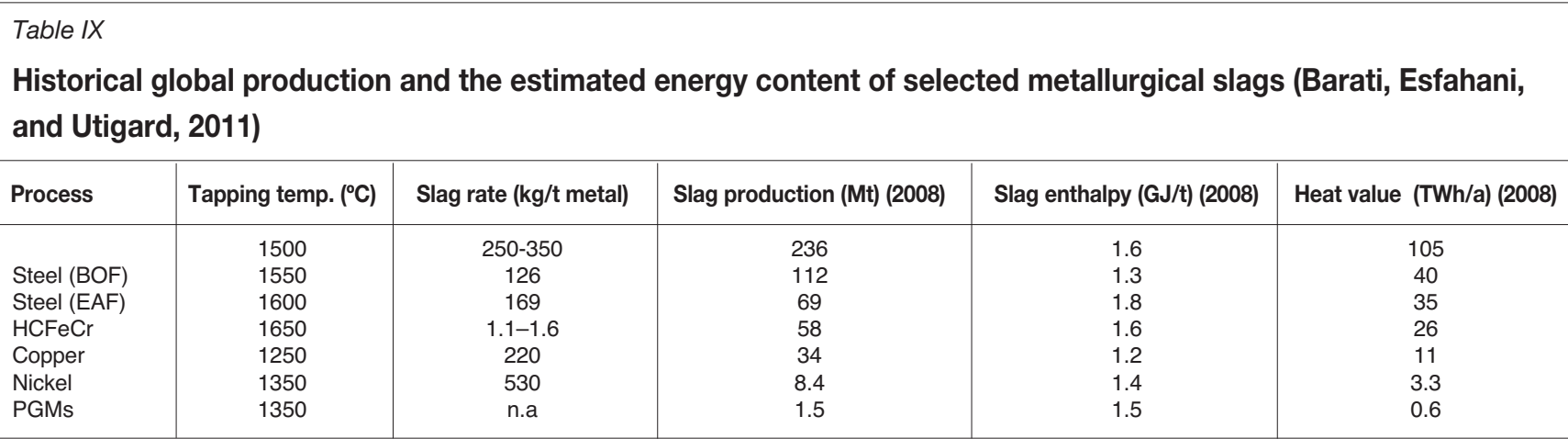




\section{Mining and metallurgical wastes: a review of recycling and re-use practices}

as the heat carrier. The findings indicated that: (1) the amount of hydrogen at a steam-to-coal ratio of 2 increased until peak temperatures of $450-550^{\circ} \mathrm{C}$, (2) increasing the pressure from $0.1 \mathrm{MPa}$ to $10 \mathrm{MPa}$ at $775^{\circ} \mathrm{C}$ adversely affected the yield of hydrogen, and (3) an increase in slag basicity had a positive effect on the yield of hydrogen, particularly at low temperatures.

Sun et al. (2015a) also proposed a process to recover waste heat and iron from high-temperature $\left(1450-1650^{\circ} \mathrm{C}\right)$ steelmaking slags by integrating the gasification of coal with the treatment of steel slag. The proposed process resulted not only in an improved yield of syngas, but also enabled the potential recovery of iron units by magnetic separation due to the oxidation of $\mathrm{FeO}$ to $\mathrm{Fe}_{3} \mathrm{O}_{4}$ in the slag. Sun et al. (2015c) investigated the kinetics of low-temperature $\left(250-500^{\circ} \mathrm{C}\right)$ gasification of biomass combined with heat recovery from slag. Based on the catalytic effect of slags, the findings indicate that the addition of slag increased the production of syngas in the temperature range $425-500^{\circ} \mathrm{C}$. In earlier studies, Maruoka et al. (2004) demonstrated significant financial benefits of recovering waste heat in the steelmaking industry from the $\mathrm{CH}_{4}-\mathrm{H}_{2} \mathrm{O}$ reforming process using a chemical recuperator. Similarly, Purwanto and Akiyama (2006) studied the production of hydrogen by introducing a $\mathrm{CH}_{4}-\mathrm{H}_{2} \mathrm{O}$ gas mixture into a packed bed of steelmaking slag. Based on the conditions investigated $\left(700-1000^{\circ} \mathrm{C}\right.$, constant flow rate, and atmospheric pressure), the findings indicate that the slag acted not only as thermal medium but also as a catalyst to the reforming reactions (Purwanto and Akiyama, 2006).

The findings highlighted so far present a strong business case for further optimizing the processes to recover the sensible energy from molten metallurgical slags. The kinetic models developed in the various studies also demonstrate the multiple roles of metallurgical slags in coal/biomass gasification and methane-steam reforming processes; that is, not only as a thermal carrier but also as a catalyst and reactant (Maruoka et al., 2004; Purwanto and Akiyama, 2004; Duan et al., 2014a, 2004b; Sun et al., 2015a, 3025b, 2015c, 2016b, 2017; Duan, Yu, and Wang, 2017).

Synthesis of functional materials from solidified slagsMetallurgical slags have a great potential as feedstocks in the production of novel functional materials such as sintered glass-ceramics (Rawlings, 1994; Gorokhovsky et al., 2002; Rawlings, Wu, and Boccaccini, 2006; Zanotto, 2010; Ponsont and Bernado, 2013; Bai et al., 2016; Liu, Zong, and Hou, 2016), porous ceramic materials (Tanaka, Yoshikawa and Suzuki, 2009; Nikitin, Kol'tsova, and Beliy, 2013; Suzuki, Tanaka, and Yamasaki, 2014; Sun and Guo, 2015), ceramic bricks (Nel and Täuber, 1970; Shih, White, and Leckei, 2006; Quijorma, San-Miguel, and Andrés, 2011; Karayannis et al., 2017), functional zeolites for waste water treatment (Kuwahara et al., 2010; Chen et al., 2012; Li et al., 2016), and refractory materials (Gu et al., 2018), among other applications. Of particular interest in the context of this paper is the synthesis of functional glass-ceramics and zeolites from metallurgical slags.

Glass-ceramics are fine-grained polycrystalline materials formed when glasses of suitable composition are heat treated to undergo controlled crystallization to the lower energy crystalline state (Rawlings, 1994; Bai et al., 2016). To date, sintered functional glass-ceramics have attracted considerable attention as low-cost alternatives to conventional glass-ceramic manufacturing (Ponsot et al., 2015). These materials have novel applications in a wide variety of industries, ranging from catalysis to thermal insulation, lightweight structural support, cooking ware, ceramic tiles, and military applications (Rawlings, $\mathrm{Wu}$, and Boccaccini, 2006; Zanotto, 2010; Ponsot et al., 2015). In that regard, the manufacture of sintered glass-ceramics with functional properties such as catalytic activity, optical and electrical properties, and desirable mechanical properties, using $\mathrm{CaO}-\mathrm{Al}_{2} \mathrm{O}_{3}-\mathrm{SiO}_{2}-\mathrm{MgO}-\mathrm{FeO}$ - based metallurgical slags has also drawn considerable attention in recent years (Gorokhovsky et al., 2002; Chinnam et al., 2013; Ponsot and Bernado, 2013; Bai et al., 2016; Liu, Zong and Hou, 2016). Liu, Zong and Hou (2016) investigated the effect of $\mathrm{MgO} / \mathrm{Al}_{2} \mathrm{O}_{3}$ addition on crystallization behaviour, microstructure, mechanical properties, and chromium solidification performance of glass-ceramics synthesized using EAF slag. Their findings indicate that $\mathrm{MgO} / \mathrm{Al}_{2} \mathrm{O}_{3}$ ratios of 1:1 and 1:2 resulted in improved mechanical and chromium fixation properties. Ponsot and Bernado (2013) investigated the manufacture of self-glazed glass-ceramic foams from iron-rich metallurgical slags and recycled glass. Homogenous foaming and specific mechanical properties comparable to those of conventional porcelain stoneware sintered above $1100^{\circ} \mathrm{C}$ were obtained. Bai et al. (2016) investigated the synthesis of glass-ceramics using highcarbon ferrochromium (HCFeCr) slag and waste glass. In addition to microstructural and mechanical properties comparable to other slag-based glass-ceramics, the findings demonstrated the evolution of stable $(\mathrm{Mg}, \mathrm{Fe})_{2} \mathrm{SiO}_{4}, \mathrm{MgAl}_{2} \mathrm{O}_{4}$, $\mathrm{Mg}(\mathrm{Al}, \mathrm{Cr})_{2} \mathrm{O}_{4}$, and $\mathrm{Cr}_{2} \mathrm{O}_{3}$ phases which are desirable in reducing toxicity of the HCFeCr slags (Bai et al., 2016). As demonstrated by the various studies, the incorporation of metallurgical slags into functional glass-ceramics not only increases the low-cost recyclability and re-use opportunities of the slags, but also results in the formation of stable phases with low TCLPs.

Synthesis of functional zeolites from slags-Zeolites are crystalline porous solids with intricate pore and channel systems in the molecular sieve range of 0.3$3 \mathrm{~nm}$ (Li et al., 2016). Basically, zeolites are crystalline aluminosilicates, with group I or group II elements as counter-ions (Simate et al., 2016). The structure of zeolite consists of a framework of $\left[\mathrm{SiO}_{4}\right]^{4-}$ and $\left[\mathrm{AlO}_{4}\right]^{5-}$ tetrahedra linked to each other at the corners by sharing oxygen atoms (Simate et al., 2016; Li et al., 2016; Mallapur and Oubagaranadin, 2017). In general, these materials are commonly used as commercial absorbents and catalysts (Simate et al., 2016; Li et al., 2016; Mallapur and Oubagaranadin, 2017). Functional zeolites produced by the hydrothermal treatment of silicate-rich slags have widespread applications in waste water treatment and in the remediation of AMD (Kuwahara et al., 2010; Lin et al., 2016; Simate et al., 2016). For example, Li et al., (2016) investigated the synthesis of sodium aluminate $\left(6 \mathrm{Na}_{2} \mathrm{O} \cdot 6 \mathrm{Al}_{2} \mathrm{O}_{3} \cdot 12 \mathrm{SiO}_{2}\right)$ and sodalite $\left(4 \mathrm{Na}_{2} \mathrm{O} \cdot 3 \mathrm{Al}_{2} \mathrm{O}_{3} \cdot 6 \mathrm{SiO}_{2}\right)$ zeolites using Ti-bearing EAF slag as a precursor. The performance of the crystalline zeolites, synthesized based on the design parameters such as molar ratios of $\mathrm{SiO}_{2} / \mathrm{Al}_{2} \mathrm{O}_{3}$ (ratio 2:1) and $\mathrm{H}_{2} \mathrm{O} / \mathrm{Na}_{2} \mathrm{O}$ (ratio 


\section{Mining and metallurgical wastes: a review of recycling and re-use practices}

$100: 1)$, and hydrothermal temperature $\left(140^{\circ} \mathrm{C}\right)$ and time (3 hours), was evaluated based on the removal of $\mathrm{Cu}^{2+}$ ions from aqueous solutions. In other studies, Kuwahara et al. (2010) proposed an acid leaching and $\mathrm{NaOH}$ precipitation method to synthesise hydrotalcite-like compounds $\left(\mathrm{Mg}_{3} \mathrm{Al}(\mathrm{OH})_{8} \mathrm{Cl} \cdot 2 \mathrm{H}_{2} \mathrm{O}\right.$ and $\left.\mathrm{Mg}_{6} \mathrm{Al}(\mathrm{OH})_{16} \mathrm{CO}_{3} \cdot 4 \mathrm{H}_{2} \mathrm{O}\right)$ and zeolites from blast furnace slags. Based on the absorptive capacity of the phosphate ions, the comparative performance of synthesised hydrotalcite and zeolite materials was significantly higher at $40 \mathrm{mg}$ and $333 \mathrm{mg}$ of phosphorus per gram, respectively, compared to $1.5 \mathrm{mg}$ of phosphorus per gram for raw slag. Due to the novel heavy-metal absorption properties and the environmental challenges associated with heavy-metals-laden waste water and AMD, the synthesis of functional zeolites using metallurgical slags as precursors thus provides low-cost opportunities for the utilization of these materials.

\section{Recycling and recovery of value metals from post- consumer wastes}

As highlighted in Table I, post-consumer waste refers to different types of waste generated by households or commercial, industrial, and institutional facilities in their role as end-uses of the products, which can no longer be used for their initial purposes. The increasing global population, coupled with advances in technology and increased consumption of natural resources, has led to dramatic increases in the flow of these anthropogenic materials (Johnson et al., 2007; Dodson et al., 2012; Jin, Kim, and Guillaume, 2016; Park et al., 2017). As a result, postconsumer wastes present environmental challenges in modern society as any leftover and/or obsolete products are often discarded. Typically, these anthropogenic materials are disposed in landfills, thereby creating environmental challenges (Birloaga et al., 2013; Corder, Golev, and Guirco, 2015; Ongondo, Williams, and Whitlock, 2015; Ndlovu, Simate, and Matinde, 2017). On the other hand, increasing the recovery of metals from post-consumer products in anthropogenic spaces has intrinsic business, socioeconomic, and technological advantages (Hagelüken et al., 2016; Sun et al., 2016). In other words, considering these materials as anthropogenic sources of secondary resources that can be recycled and re-used can result in reduced environmental damage while supporting sustainable development goals through the efficient use of resources (Ongondo, Williams, and Whitlock, 2015; Corder, Golev, and Guirco, 2015; Ndlovu, Simate, and Matinde, 2017).

The recycling and re-use of post-consumer waste provides incentives to shift away from the traditional linear use of resources to a closed-loop, cyclical utilization of resources that allows for maximum recovery of resources from waste (Cossu, 2013; Ongondo, Williams, and Whitlock, 2015; Sun et al., 2015d, 2016). Of particular interest in the context of this paper is the recovery of precious metals from spent autocatalysts and electronic waste (e-waste). Spent autocatalysts and e-waste contain significant amounts of high-value metals such as $\mathrm{Pt}, \mathrm{Rh}, \mathrm{Pd}, \mathrm{Cu}, \mathrm{Ni}$, and $\mathrm{Au}$, among others. To date, extensive research based on pyrometallurgical and hydrometallurgical processing, or combinations of both, has been conducted in order to recover precious and other valuable metal elements from these types of wastes (Johnson et al., 2007; Cui and Zhang, 2008; Birloaga et al., 2013; Binnemans et al., 2013; Itoh, 2014; Yang, Zhang, and Fang, 2014; Akcil et al., 2015; Sun et al., 2015c; Corder, Golev, and Guirco, 2015; Ongondo, Williams, and Whitlock, 2015; Jadhav and Hocheng, 2015; Jin, Kim, and Guillaume, 2016; Sun et al., 2015d, 2016; Lu and Xu, 2016; Hagelüken et al., 2016; Ndlovu, Simate, and Matinde, 2017; Wang et al., 2017b).

Pyrometallurgical processes involve heating the waste materials at high temperatures to recover the valuable metals. Typical unit processes such as plasma smelting, conventional submerged arc, top submerged lance, chlorination, and volatilization, among others, have widely been adopted in the processing of these wastes (Cui and Zhang, 2008; Jadhav and Hocheng, 2015; Wang et al., 2017b). Despite the fast kinetics and favourable thermodynamics as a result of hightemperature conditions, pyrometallurgical processes have several inherent constraints such as high energy footprints and the need for intricate off-gas cleaning systems (Tuncuk et al., 2012; Jadhav and Hocheng, 2015). Due to the presence of polymers, ceramics, and halogenated flame retardants in some of these waste streams, the formation of highly toxic volatile compounds such as polychlorinated dibenzo-pdioxins and dibenzol furans (PCDD/Fs), polybrominated diphenyl ethers (PBDEs), and polycyclic aromatics, among others, is also a major challenge in most of these processes (Johnson et al., 2007; Tuncuk et al., 2012; Jadhav and Hocheng, 2015; Lu and Xu, 2016; Cui and Anderson, 2016). As a result of the structural challenges associated with conventional pyrometallurgical processes, hydrometallurgical processes have been developed as alternatives in order to improve the economics of extraction of valuable metals from spent autocatalysts and e-wastes.

To date, extensive research has been conducted to recover precious metals from spent autocatalysts and e-waste using both conventional aqueous and emerging non-aqueous leaching and chelating media (Tuncuk et al., 2012; Birloaga et al., 2013; Binnemans et al., 2013; Itoh, 2014; Park et al., 2014; Yang et al., 2014; Sun et al., 2015d; Jadhav and Hocheng, 2015; Corder, Golev, and Guirco, 2015; Ongondo, Williams, and Whitlock, 2015; Sun et al., 2015e; 2016; Lu and $\mathrm{Xu}, 2016$; Cui and Anderson, 2016; Ndlovu, Simate, and Matinde, 2017; Wang et al., 2017b). So far, several processes have been developed to recover metals using acidic media (Syed, 2006; Park and Fray, 2009; Yang, Zhang, and Fang, 2014; Jadhav and Hocheng, 2015; Cui and Anderson, 2016), complexing agents such as cyanide, halides, thiosulphate, and thourea (Jadhav and Hocheng, 2015; Cui and Anderson, 2016; Akcil et al., 2015; Lu and Xu, 2016) and biohydrometallurgy (Cui and Zhang, 2008). Recently, attention has focused on the recovery of precious elements from spent autocatalysts and e-waste using ionic liquids (Binnemans et al., 2013; Sun et al., 2015d; Park et al., 2014; Rzelewska et al., 2017). As discussed earlier, ionic liquids are low-temperature molten salts comprising cations and organic/inorganic anions, and are increasingly being investigated for the extraction of metals due to their desired properties such as non-volatility, low toxicity, good ionic conductivity, and wide electrochemical potential window (Park et al., 2014). The recovery of valuable metals from spent autocatalysts and e-waste using ionic liquids provides 


\section{Mining and metallurgical wastes: a review of recycling and re-use practices}

several advantages such as high selectivity, ability to recover the valuable metals in their pure state, and the ability to detoxify and produce environmentally benign residues.

Although research into the recycling of spent autocatalysts and e-waste for metal recovery and the generation of other valuable products has been widespread, large scale production plants dedicated solely to the processing of these wastes material are still to be universally adopted. This is mainly due to the fact that metal recycling plants are capital-intensive and expensive to set up. Furthermore, the success of these interventions is also predicated on a consistent and uniform supply of waste materials, thereby competing with similar products from primary raw materials (Johnson et al., 2007; Dodson et al., 2012; Corder, Golev, and Guirco, 2015; Sun et al., 2016). As a result, the major driver for the success of recycling initiatives so far has been to blend and incorporate the recycled materials with other materials into the existing primary and/or secondary processes for metal extraction.

\section{Integration with engineering education}

The previous sections discussed in detail the technical aspects of recycling and re-use of mining and metallurgical wastes. As discussed earlier, the recycling and re-use of these waste materials is important from an economic, environmental, and industrial point of view. Therefore, in order to maximize the benefits, new systems thinking approaches are crucial to leverage on the circularity and recyclability of some of these materials. For example, the sustainability of the mining and metallurgical industries can be greatly enhanced by incorporating an environmentally friendly way of treating the process residues and/or byproducts generated in the extraction of metals and mineral commodities. In other words, improving the circularity of the various waste materials requires multidisciplinary recycling and re-use initiatives that take into account the initial stages of developing a new material and/or process (Person, 1971; Pech-Canul and Kongoli, 2016). Based on the aforementioned discussions, several researchers have highlighted the early career education and training of design and process engineers as essential components in the dynamics of environmental protection and sustainable consumption of natural resources (Bishop, 2000; GutierrezMartin and Hüttenhain, 2003; Boyle, 2004; Hering, 2012; Pech-Canul and Kongoli, 2016; UNESCO, 2010. 2017).

To date, the integration of aspects of sustainability into the engineering curriculum has broadly been driven by the need to address complex societal and socio-economic problems arising from the negative externalities of industrial processes and products (Bishop, 2000; Gutierrez-Martin and Hüttenhain, 2003; Boyle, 2004; Kastenhofer, Lansu, and van Dam-Mieras, 2010; Pech-Canul and Kongoli, 2016; UNESCO, 2017). Obviously, the protracted industrial growth experienced in the 21 st century has not only led to the unsustainable use and consumption of natural resources, but has also resulted in unstainable levels of environmental degradation and pollution (Kastenhofer, Lansu, and van Dam-Mieras, 2010). To a greater extent, the emerging paradigms on environmental stewardship have ignited a debate on the role of engineering education in preparing graduates' interdisciplinary and transdisciplinary ethos of sustainable development (Tilbury, 1995; ABET, 2009; Kastenhofer, Lansu, and van Dam-Mieras, 2010; Vanderburg, 1999; Guerra, 2017; UNESCO, 2010; 2017). For example, UNESCO (2017) explicitly proposed the need for responsive education systems based on pedagogies that empower learners and include sustainability principles. In particular, UNESCO (2017) clearly stipulates the need for institutions to initiate and disseminate engineering curricula that integrate sustainability and sustainable development.

In view of these emerging paradigms in engineering education, extensive debate is now centred on the holistic integration of these issues into the broad engineering teaching and learning space. In principle, the various education systems globally have converged on explicit sets of statements and principles on learning outcomes, desired graduate attributes, and professional competencies relevant to sustainable development. Possible approaches include facilitating active learning and development of higher order cognitive skills on sustainability by:

(1) Incorporating environmental aspects in the design tasks of the various courses covering the unit processes producing the waste materials (Vanderburg, 1999; Boks and Diehl, 2006; Zimmerman and Anastas, 2009; Zoller, 2013)

(2) Research-based teaching in order to develop cognitive enquiry skills through experiential learning (Kolb, 1984; Grimson, 2002; Healy, 2005; Zoller, 2013; Hedden et al., 2017)

(3) Alignment of individual academics' agency into the teaching and learning of sustainability principles (Cebrián and Junyent, 2015; Colombo and Mattarolo, 2017; Hedden et al., 2017).

\section{Conclusion}

The increasing global population, coupled with advances in technology and increased consumption of resources, has led to a dramatic increase in the flow of anthropogenic materials. However, the linear model of resources consumption obviously results in high levels of waste from the mining, metallurgical, and industrial processing of virgin raw materials. Inasmuch as the production of mining and metallurgical wastes is inevitable in the production of industrial materials, waste management practices to date have focused on how to manage the way in which the waste is generated and disposed of. However, the traditional approach to managing mining and metallurgical waste is not only unsustainable, but also discounts the circularity of most of these anthropogenic materials. Based on the emerging paradigm of a circular economy model that mandates the reduction, recycling, and re-use of wastes, this paper provided a critical review of current and emerging research on the recycling and re-use of mining and metallurgical wastes. Firstly, the paper categorized the various types of wastes in the mining and metallurgical industries and introduced some of the legislative framework governing these types of wastes. Secondly, the paper highlighted the ongoing research and emerging trends in the recycling and re-use of selected mining, metallurgical and post-consumer wastes. With a view of igniting debate, the paper provided a brief overview of the converging principles on the integration of the key aspects of sustainability into the engineering education curriculum. 


\section{Mining and metallurgical wastes: a review of recycling and re-use practices}

\section{References}

ABET. 2009. Criteria for accrediting engineering programs for evaluations during 2010-2011 accreditation cycles. Baltimore, MD. http://www.abet.org/wp-content/uploads/2015/04/criteria-eac-20102011.pdf [accessed 24 November 2017].

Aввотt, P.A., Capper, G., Davies, D.L., Rasheed, R.K., and ShiKotra, P. 2005. Selective extraction of metals from mixed oxide matrices using cholinebased ionic liquids. Inorganic Chemistry Communication, vol. 44. pp. 6497-6499.

AвbotT, P.A., CAPPER, G., DAVIES, D.L., McKenZIE, K.J., and OBI, S.U. 2006a. Solubility of metal oxides in deep eutectic solvents based on choline chloride. Journal of Chemical and Engineering Data, vol. 51. pp. 1280-1282.

Aвbott, A.P., CAPper, G., Davies, D.L., and Shiкotra, P. 2006b. Processing of metal oxides using ionic liquids. Mineral Processing and Extractive Metallurgy, vol. 115, no. 1. pp. 15-18.

Abbott, A.P., Collins, J., Dalrymple, I., Harris, R.C., Mistry, R., QIU, F., Scheirer, J., and WISE, W.R. 2009. Processing of electric arc furnace dust using deep eutectic solvents. Australian Journal of Chemistry, vol. 62. pp. 341-347.

Aвbott, P.A., Frisch, G., Hartley, J., and Ryder, K.S. 2011. Processing of metals and metal oxides using ionic liquids: Critical review. Green Chemistry, vol. 13. pp. 471-481.

ABdulLah, M.O. 2013. Applied Thermal Energy: An Introduction. Taylor \& Francis/CRC Press, Boca Raton, FL.

AKClL, A. and KolDAs, S. 2006. Acid mine drainage (AMD): causes, treatment and case studies. Journal of Cleaner Production, vol. 14. pp. 1139-1145.

AKcll, A., Erust, C., Gahan, C.S., Ozgun, M., SAhin, M., and Tunkuk, A. 2015. Precious metal recovery from waste printed circuit boards using cyanide and non-cyanide lixiviants: A review. Waste Management, vol. 45. pp. 258-271.

Albertsson, G.J., Teng, L., and BjörKman, B. 2014. Effect of basicity on chromium partition in $\mathrm{CaO}-\mathrm{MgO}-\mathrm{SiO}_{2}-\mathrm{Cr}_{2} \mathrm{O}_{3}$ synthetic slag at $1873 \mathrm{~K}$. Transactions of the Institution of Mining and Metallurgy Section B: Mineral Processing and Extractive Metallurgy, vol. 132, no. 2. pp. 116-122.

AlberTsson, G.J. 2013. Abatement of chromium emissions from steelmaking slags-Cr stabilization by phase separation. Doctoral thesis, Royal Institute of Technology. Stockholm, Sweden.

Amarasekara, A.S. 2016. Acidic ionic liquids. Chemical Reviews, vol. 116. pp. 6133-6183.

Bai, Z., Qui, G., Pend, B., Guo, M., and Zhang, M. 2016. Synthesis and characterization of glass-ceramics prepared from high carbon ferrochromium slag. RCS Advances, vol. 6. pp. 52715-52723.

ВАККАR, A. 2014. Recycling of electric furnace dust through dissolution in deep eutectic ionic liquids and electrowinning. Journal of Hazardous Materials, vol. 280. pp. 191-199.

Balintova, M. and Petrilakova, A. 2011. Study of pH Influence of selective precipitation of heavy metals from acid mine drainage. Chemical Engineering Transactions, vol. 25. pp. 1-6.

Barati, M., Esfahani, S., and Utigard, T.A. 2011. Energy recovery from high temperature slags. Energy, vol. 36. pp. 5440-5449.

Barbieri, L., Leonelli, C., Manfredini, T., Pellacani, G.C., Siligardi, C., TONDELLO, E., and BERTONCELLO, R. 1994. Solubility, reactivity and nucleation effect of $\mathrm{Cr}_{2} \mathrm{O}_{3}$ in the $\mathrm{CaO}-\mathrm{MgO}-\mathrm{Al}_{2} \mathrm{O}_{3}-\mathrm{SiO}_{2}$ glassy system. Journal of Materials Science, vol. 29. pp. 6273-6280.

BARBieri, L., CoRradi, A., and LANCELlotti, I. 2002. Thermal and chemical behavior of different glasses containing steel fly ash and their transformation into glass-ceramics. Journal of the European Ceramic Society, vol. 22. pp. 1759-1765.

BeUKES, J.P., van ZyL, P.G., and RAS, M. 2012. Treatment of Cr (VI)-containing wastes in the South African ferrochrome industry - a review of currently applied methods. Journal of the Southern African Institute of Mining and Metallurgy, vol. 112. pp. 347-352.

Bian, Z., Miao, X., Lei, S., Chen, S., Wang, W., and Struthers, S. 2012. The challenges of recycling mining and mineral processing wastes. Science, vol. 337, no. 6095. pp. 702-703.

BinNEMANS, K. and JonEs, P.T. 2017. Solvometallurgy: An emerging branch of extractive metallurgy. Journal of Sustainable Metallurgy, vol. 3, no. 3 . pp. 570-600.

Binnemans, K., Jones, P.T., BlainPain, B., van Gerven, T., Yang, Y., Walton, A. and BucherT, M. 2013. Recycling of rare earths: A critical review. Journal of Cleaner Production, vol. 51. pp. 1-22.

Birloaga, I., De Michelis, I., Ferella, F., Buzatu, M., and Vegliò, F. 2013. Study on the influence of various factors in hydrometallurgical processing of waste printed circuit boards for copper and gold recovery. Waste Management, vol. 33. pp. 935-941.
BisHoP, P.L. 2000. Pollution prevention: A new paradigm for engineering education. Environmental Challenges. Belkin S. (ed.). Springer, Dordrecht. p. 506.

Bisio, G. 1997. Energy recovery from molten slag and exploitation of the recovered energy. Energy, vol. 22, no. 5. pp. 501-509.

BoKs, C. and DieHL, J.C. 2006. Integration of sustainability in regular courses: experiences in industrial design engineering. Journal of Cleaner Production, vol. 14. pp. 932-939.

BoyLe, C. 2004. Considerations on educating engineers in sustainability. International Journal of Sustainability in Higher Education, vol. 5, no. 2. pp. 147-155.

Burja, J., Tehovnik, F., Vode, F., Godec, M., Arh, B., and Medved, J. 2017. Precipitation of metallic chromium during rapid cooling of $\mathrm{Cr}_{2} \mathrm{O}_{3}$ slags. Metabk, vol. 56, no. 1. pp. 13-16.

Cabrera-Real, H., Romero-Serrano, A., Zeifert, B., Henarndez-Ramirez, A. Hallen-Lopez, M., and Cruz-Ramirez, A. 2014. Effect of MgO and $\mathrm{CaO} / \mathrm{SiO}_{2}$ on the immobilization of chromium in synthetic slags. Journal of Materials Cycles and Waste Management, vol. 14. pp. 317-324.

Cebrián, G. and Junyent, M. 2015. Competencies in education for sustainable development: Exploring the student teachers views. Sustainability, vol. 7. pp. 2768-2786.

ChairaKsa-Fujimoto, R., Inoue, Y., Umeda, N., Itoh, S., and NAGASAKa, T. 2015. New pyrometallurgical process of EAF dust treatment with $\mathrm{CaO}$ addition. International Journal of Minerals, Metallurgy and Materials, vol. 22, no. 8. pp. 788-797.

Chairaksa-Fujimoto, R., Maruyama, K., Мiki, T., and Nagasaka, T. 2016. The selective leaching of zinc oxide from electric arc furnace dust pre-treated with calcium oxide. Hydrometallurgy, vol. 159. pp. 120-125.

Chinnam, R.K., Francis, A.A., Will, J., Bernado, E., and Boccaccini, A.R. 2017 Review: Functional glasses and glass-ceramics derived from iron-rich waste and combination of industrial residues. Journal of Non-Crystalline Solids, vol. 365. pp. 63-75.

CHOWDHURY, A.R.. SARKAR, D., and DATTA, R. 2015. Remediation of acid mine drainage-impacted water. Current Pollution Reports, vol. 1. pp. 131-141.

Colombo, E. and Mattarolo, L. 2017. Energy and development: the role of academia in education, research, and technological cooperation for sustainability. Wiley Interdisciplinary Reviews Energy and Environment, vol. 6. pp. 1-12.

CoRder, G.D., Golev, A., and Guirco, D. 2015. Wealth from metals: Translating global knowledge on industrial ecology to metals recycling in Australia. Minerals Engineering, vol. 76. pp. 2-9.

Cossu, R. 2013. Urban mining concept. Waste Management, vol. 33, no. 3 . pp. 497-497.

CuI, H. and ANDERSON, C.G. 2016. Literature review of hydrometallurgical recycling of printed circuit boards (PCBs). Journal of Advanced Chemical Engineering, vol. 6, no. 1. pp. 1-11.

Davris, P., Balomenos, E., Panias, D. and Paspaliaris, I. 2016. Selective leaching of rare earth elements from bauxite (red mud) using functionalised hydrophobic ionic liquid. Hydrometallurgy, vol. 164. pp. 125-135.

DE Buzin, P.J.W.K., HECK, N.C., and VILELA, A.C.F. 2017. EAF dust: An overview on the influences of physical, chemical and mineral features in its recycling and waste incorporation routes. Journal of Materials Research and Technology, vol. 6, no. 2. pp. 194-202.

Department of Science and Technology. 2014. A waste research, developing and innovation roadmap for South Africa (2015-2025). Summary Report Department of Science and Technology, Pretoria. https://www.wasteroadmap.co.za/download/waste_rdi_roadmap_ summary.pdf [accessed 20 November 2017].

DEPARTMENT OF WATER AND ENviRonMEnT. 2010. National Environmental Management Act (Act No. 107 of 1998). Republic of South Africa. http://www.dwa.gov.za/Groundwater/ Documents/EIA\%20 Regs\%20listing\%20Notice1.pdf [accessed 27 January 2018.

Dodson, J.R., Hunt, A.J., PARKer, H.L., YANG, Y., and Clark, J.H. 2012. Elemental sustainability: Towards the total recovery of scarce metals. Chemical Engineering and Processing: Process Intensification, vol. 51. pp. 69-78.

DuAn, W., Yu, Q., and WANG, Z. 2017. Comprehensive analysis of the coal particle in molten blast furnace slag to recover waste heat. Energy and Fuels, vol. 31. pp. 8813-8819.

Duan, W., Yu, O., Zuo, Z., Oin, O., Li, P., and Liu, J. 2014a. The technological calculation for synergistic system of BF slag waste heat recovery and carbon resources reduction. Energy Conservation and Management, vol. 87. pp. 185-190.

Duan, W., Yu, Q., XIE, H., QIN, Q., and Zuo, Z. 2014b. Thermodynamic analysis of hydrogen-rich gas generation from coal/steam gasification using blast furnace slag as a heat carrier. International Journal of Hydrogen Energy, vol. 39. pp. 11611-11619. 


\section{Mining and metallurgical wastes: a review of recycling and re-use practices}

Durinck, D., Engstrom, F., Arnout, S., Heulens, J., Jones, P.T., Bjorkman, B. Blainpain, B. and Wollants, P. 2008a. Hot stage processing of metallurgical slags. Resources, Conservation and Recycling, vol. 52. pp. 1121-1131.

Durinck, D., Arnout, S., Merten, G., Boydens, E., Jones, P.T., Elsen, J., Blainpain, B., and Wollants, P. 2008b. Borate distribution in stabilized stainless steel slag. Journal of the American Ceramic Society, vol. 91, no. 2. pp. 548-554.

Edraki, M., Baumgartl, T., Manlapig, E., Bradshaw, D., Franks, D.M., and MoRAN, C.J. 2014. Designing mine tailings for better environmental, social and economic outcomes: A review of alternative approaches. Journal of Cleaner Production, vol. 84. pp. 411-420.

Engström, F., Adolfssson, D., Yang, Q., SAmuelsson, C., and Björkman, B. 2010. Crystallization behavior of some steelmaking slags. Steel Research International, vol. 81, no. 5. pp. 362-371.

Environmental Protection Agency. 2015. Rules and Regulations. Federal Register 80 (8), Tuesday, January 13, 2015. US Federal Government. https://www.gpo.gov/fdsys/pkg/FR-2015-01-13/pdf/FR-2015-01-13.pdf [accessed 31 October 2017]

European Commission. 2006. Directive 2006/21/EC of the European Parliament and of the Council on the management of waste from extractive industries. http://ec.europa.eu/environment/waste/mining/legis.htm [accessed 27 January 2018].

EuRoPeAn Commission. 2008. Waste management legislation (Section 4). Handbook on the Implementation of EC Environmental Legislation. http://ec.europa.eu/environment/archives/enlarg/handbook/waste.pdf [accessed 31 October 2017]

EUROPEAN COMMISSION. 2010a. Reference documents under the IPPC Directive and the IED. Circular Economy and Industrial Leadership, European Commission Joint Research Centre. http://eippcb.jrc.ec.europa.eu/reference/ [accessed 31 October 2017].

EuRopean Commission. 2010b. Industrial emissions (integrated pollution prevention and control). Directive 2010/75/EU of the European Parliamen and of the Council. http://eur-

lex.europa.eu/LexUriServ/LexUriServ.do?uri=OJ:L:2010:334:0017:0119:e n:PDF [accessed 30 January 2018].

EuRopean Commission. 2015. Closing the Loop: An EU Action Plan for Circular Economy. COM 614/2. European Commission, Brussels. http://eurlex.europa.eu/resource.html?uri= cellar:8a8ef5e8-99a0-11e5-b3b701aa75ed71a1.0012.02/DOC_1\&format=PDF [accessed 24 November 2017].

EuRosLAG. 2017. Slag: A high grade product out of a high quality controlled industry. Euroslag. http://www.euroslag.com/products/ [accessed 22 November 2017].

Flanagán, C., Grail, B.M., and Johnson, D.B. 2017. New approaches for extracting and recovering metals from mine tailings. Minerals Engineering, vol. 106. pp. 71-78.

GoRAKHKI, M.H. and BAREITHER, C.A. 2017. Sustainable reuse of mine tailings and waste rock as water-balance covers. Minerals, vol. 7, no. 128. pp. 1-17.

GorokHovsky, A., Escalante-Garcia, J.I., Gorokhovsky, V., and Mescheryakov, D. 2002. Inorganic wastes in the manufacture of glass and glass-ceramics: Quartz-feldspar waste of ore refining, metallurgical slag, limestone dust, and phosphorus slurry. Journal of American Ceramic Society, vol. 85, no. 1. pp. 285-287.

GRIMSON, J. 2002. Re-engineering the curriculum for the 21st century. European Journal of Engineering Education, vol. 27, no. 1. pp. 31-37.

GuERRA, A. 2017. Integration of sustainability in engineering education: Why is PBL an answer? International Journal of Sustainability in Higher Education, vol. 18, no. 3. pp. 436-454.

Gu, F., Peng, Z., Zhang, Y., Tang, H., Ye, L., Tian, W., Liang, G., Rao, M., Li, G., and JiANG, T. 2018. Facile route for preparing refractory materials from ferronickel slag with addition of magnesia. ACS Sustainable Chemistry and Engineering, vol. 6. pp. 4880-4889.

GutierReZ-Martin, F. and HütTENHAN, S.H. 2003. Environmental education New paradigms and engineering syllabus. Journal of Cleaner Production, vol. 11. pp. 247-251.

HA, T.K., Kwon, B.K., PARK, K.S., and Mohapatra, D. 2015. Selective leaching and recovery of bismuth as $\mathrm{Bi}_{2} \mathrm{O}_{3}$ from copper converter dust. Separation and Purification Technology, vol. 142. pp. 116-122

HagelüKen, C., Lee-Shin, J.U., Carpentier, A., and Heron, C. 2016. The EU circular economy and its relevance to metal recycling. Recycling, vol. 1. pp. 242-253.

HEALEY, M. 2005. Linking research and teaching: Exploring disciplinary spaces and the role of inquiry-based, learning. Reshaping the University: New Relationships between Research, Scholarship and Teaching. Barnett, $\mathrm{R}$. (ed.). McGraw Hill/Open University Press. pp. 67-78.
Hedden, M.K., Worthy, R., Akins, E., Suinger-Friedman, V., and Paul, R.C. 2017. Teaching sustainability using an active learning constructivist approach: discipline-specific case studies in higher education. Sustainability, vol. 9 , no. 1320 . pp. $1-18$

HeRing, J.G. 2012. An end to waste? Science, vol. 337, no. 6095. p. 623.

Huang, X., Yu, L., Li, D.W., ShiAu, Y.C., LI, S., and Liu, K.X. 2015. Preparation and properties of geopolymers from blast furnace slag. Materials Research Innovations, vol. 19, no. S10. pp. 413-419.

Ітон, Н. 2014. The recent trends of e-waste recycling and rare metal recovery in Japan. WIT Transactions on Ecology and the Environment, vol. 180. pp. 3-14.

JADHAV, U. and HochENG, H. 2015. Hydrometallurgical recovery of metals from large printed circuit board pieces. Scientific Reports, vol. 5, no. 145740. pp. 1-9.

Jiang, L., Bao, Y., Chen, Y., Liu, G., Han, F., YAnG, Q., and Wu, J. 2018. Experimental investigation on BOF slag oxidation in air. Ironmaking and Steelmaking, January. pp. 1-8. https://doi.org/10.1080/03019233.2017.1410945

JiN, Y., KIm, J., and Gulllaume, B. 2016. Review of critical material studies. Resources, Conservation and Recycling, vol. 113. pp. 77-87.

JoHnSon, D.B. and HALLBERG, K. B. 2005. Acid mine drainage remediation options: a review. Science of the Total Environment, vol. 338. pp. 3-14.

Johnson, J., Harper, E.M., Lifset, R., and Graendel, T.E. 2007. Dining at the periodic table: Metals concentrations as they relate to recycling. Environmental Science and Technology, vol. 41, no. 5. pp. 1759-1765.

Kalinkin, A.M., Kumar, S., Gurevich, B.I., Kalinkina, E.V., and Tyukavkina, V.V. 2014. Synthesis of geopolymer materials based on slags of nonferrous metallurgy with the use of mechanoactivation. Glass Physics and Chemistry, vol. 40, no. 1. pp. 26-30.

Karayannis, V., Ntampegliotis, K., Lamprakopoulos, S., Papapolymerou, G., and SPILIoTIS, X. 2017. Novel sintered ceramic materials incorporated with EAF steel slag. Materials Research Express, vol. 4. pp. 1-9.

KASTENHOFER, K., LANSU, A., and VAN DAM-Mieras, R. 2010. The contribution of university curricula to engineering education for sustainability. GAIA, vol. 19 , no. 1. pp. 44-51.

Kilicarslan, A., Saridede, M.N., Stopic, S., and Friedrich, B. 2014. Use of ionic liquid in leaching process of brass wastes for copper and zinc recovery. International Journal of Minerals, Metallurgy and Materials, vol. 21, no. 2. pp. 138-143.KILICARSLAN, A. and SARIDEDE, M.N. 2015. Recovery of metallic values from brass waste using Brønsted acidic ionic liquid as a leachate. Journal of Materials, vol. 67, no. 11. pp. 2739-2746.

KolB, D.A. 1984. Experiential Learning: Experiences as the Source of Learning and Development. Prentice Hall, Englewood Cliffs, NJ. pp. 25-38.

KüHn, M. AND MudersBACH, D. 2004. Treatment of liquid EAF slag from stainless steelmaking to produce environmental friendly construction materials. Proceedings of the 2nd International Conference on Process Development in Iron and Steelmaking, Luleå, Sweden, 6-9 June 2004. Vol. 2. Swerea MEFOS AB. pp. 369-377.

KumAR, U. and SINGH, D.N. 2013. E-waste management through regulations. International Journal of Engineering Inventions, vol. 3, no. 2. pp. 6-14.

Kuwahara, Y., OHmichi, T., Kamegawa, T., Mori, K. and Yamashita, H. 2010. A novel conversion process for waste slag: synthesis of hydrotalcite-like compound and zeolite from blast furnace slag and evaluation of adsorption capacities. Journal of Materials Chemistry, vol. 20. pp. 5052-5062.

LAKSHMi, M., Kumar, K.V., and Thyagarajan, K. 2016. Structural and magnetic properties of $\mathrm{Cr}$-Co nanoferrite particles. Advances in Nanoparticles, vol. 5. pp. 103-113.

LIAPIS, I. and PAPAYIANNI, I. 2015. Advances in chemical and physical properties of electric arc furnace carbon steel slag by hot stage processing and mineral mixing. Journal of Hazardous Materials, vol. 283. pp. 89-97.

LÉBRE, E. and CORDER, G. 2015. Integrating industrial ecology thinking into the management of mining waste. Resources, vol. 4. pp. 765-786.

LECLERC, N., Meux, E., AND LECUIRE, J.M. 2002. Hydrometallurgical recovery of zinc and lead from electric arc furnace dust using mononitrilotriacetate anion and hexahydrated ferric chloride. Journal of Hazardous Materials, vol. B91. pp. 257-270.

LECLERC, N., MEuX, E., and LeCuIRE, J.M. 2002. Hydrometallurgical extraction of zinc from zinc ferrites. Hydrometallurgy, vol. 70. pp. 175-183.

Li, D., Yun, H., Diroll, B.T., Doan-Nguyen, V.V.T., KiKKaWA, J.M., and Murray, C.B. 2015. Synthesis and size-selective precipitation of monodisperse nonstoichiometric $\mathrm{MxFe}_{3}-\mathrm{xO}_{4}(\mathrm{M}=\mathrm{Mn}, \mathrm{Co})$ nanocrystals and their $\mathrm{DC}$ and AC magnetic properties. Chemistry of Materials, vol. 28. pp. 480-489.

Li, Y., Peng, T., Man, W., Ju, L., Zheng, F., Zhang, M., and Guo, M. 2016. Hydrothermal synthesis of mixtures of NaA zeolite and sodalite from Tibearing electric arc furnace slag. RSC Advances, vol. 6. pp. 8358-8366. 


\section{Mining and metallurgical wastes: a review of recycling and re-use practices}

Lin, X., Peng, Z., Yan, J., Li, Z., Hwang, J.Y., Zhang, Y., Li, G., and Jiang, T. 2017. Pyrometallurgical recycling of electric arc furnace dust. Journal of Cleaner Production, vol. 149. pp. 1079-1100

Liu, Z., Zong, Y., and Hou, J. 2013. Preparation of slag glass ceramic from electric arc furnace slag, quartz sand and talc under various $\mathrm{MgO} / \mathrm{Al}_{2} \mathrm{O}_{3}$ ratios. Advances in Applied Ceramics, vol. 115, no. 3. pp. 144-151.

Liu, J., Yu, Q., Peng, J., Hu, X., and Duan, W. 2015. Thermal energy recovery from high temperature blast furnace slags. International Communications in Heat and Mass Transfer, vol. 69. pp. 23-28.

Liu, J., Yu, Q., Zuo, Z., DuAn, W., Han, Z., Qin, Q., and Yang, F. 2016. Experimental investigation on molten slags granulation for waste heat recovery from various metallurgical slags. Applied Thermal Engineering, vol. 103. pp. 1112-1118.

LotTermoser, B.G. 2011. Recycling, reuse and rehabilitation of mine wastes. Elements, vol. 7. pp. 405-410.

Lu, Y. AND Xu, Z. 2016. Precious metals recovery from waste printed circuit boards: A review of current status and perspectives. Resources, Conservation and Recycling, vol. 113. pp. 28-39.

MA, G. and Garbers-Craig, A.M. 2006. A review on the characteristics, formation mechanism and treatment processes of $\mathrm{Cr}$ (IV)-containing pyrometallurgical wastes. Journal of the Southern African Institute of Mining and Metallurgy, vol. 106. pp. 753-763.

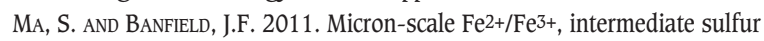
species and $\mathrm{O}_{2}$ gradients across the biofilm-solution-sediment interface control biofilm organization. Geochimica et Cosmochimica Acta, vol. 75 . pp. 3568-3580.

MA, N. and Houser, J.B. 2014. Recycling of steelmaking slag fines by weak magnetic separation coupled with selective particle size screening. Journal of Cleaner Production, vol. 82. pp. 221-231.

Machado, A.T., Valenzuela-Diaz, F.R., De Souza, C.A.C., and de Andrame Lima, L.R.P. 2011. Structural ceramics made with clay and steel dust pollutants. Applied Clay Science, vol. 51. pp. 503-506.

Macingova, E. and Luptakova, A. 2012. Recovery of metals from acid mine drainage. Chemical Engineering Transactions, vol. 28. pp. 109-114.

Mallapur, V.P. and Oubagaranadin, J.U.K. 2017. A brief review of the synthesis of zeolites from hazardous wastes. Transactions of the Indian Ceramic Society, vol. 76, no. 1. pp. 1-13.

Maruoka, N., Mizouchi,T., Purwnto, H., and Aкiуama, T. 2004. Feasibility study for recovering waste heat in the steelmaking industry using a chemical recuperator. ISIJ International, vol. 44, no. 2. pp. 257-262.

Menad, N., KAnARI, N., and SAvE, M. 2014. Recovery of high grade iron compounds from LD slag by enhanced magnetic separation techniques. International Journal on Mineral Processing, vol. 126. pp. 1-9.

Miki, T., ChairaKsa-Fujimoto, R., Maruyama, K., and NAGASAKA, T. 2016. Hydrometallurgical extraction of zinc from $\mathrm{CaO}$ treated $\mathrm{EAF}$ dust in ammonium chloride solution. Journal of Hazardous Materials, vol. 302. pp. 90-96.

MilLs, K.C., YuAn, L., and Jones, R.T. 2011. Estimating the physical properties of slags. Journal of the Southern African Institute of Mining and Metallurgy, vol. 111. pp. 649-658.

Ndlovu, S., Simate, G.S., and Matinde, E. 2017. Waste Production and Utilization in the Metal Extraction Industries. Taylor \& Francis/CRC Press, Boca Raton, FL. https://doi.org/10.1201/9781315153896

NeL, P.J. and TÄUBER, A. 1970. Use of South African blast furnace slag for ceramic purposes. Journal of the South African Institute of Mining and Metallurgy, vol. 70. pp. 366-368.

Nikitin, S., KoL'Tsova, Y., and BeliY, Y. 2013. Production of porous glasscrystalline materials using different types of natural and recycled resources. Journal of Chemical Technology and Metallurgy, vol. 48, no. 4. pp. 396-405.

Nockemann, P., This, B., Pittois, S., Thoen, J., Glorieux, C., van Hecke, K., van MeErvelt, L., Kirchner, B., and Binnemans, K. 2006. Task-specific ionic liquid for solubilizing metal oxides. Journal of Physical Chemistry, vol. B110. pp. 20978-20992.

Nockemann, P., This, B., Parac-Vogt, T.N., van Hecke, K., van Meervelt, L., Tinant, B., Hartenbach, I., Scheld, T., Ngan, V.T., Nguyen, M.T., and BinnEMAns, K. 2008. Carboxyl-functionalized task-specific ionic liquid for solubilizing metal oxides. Inorganic Chemistry, vol. 47. pp. 9987-9999.

Nordstrom, D.K.., Bowell, R.J., CAMPBELL, K.M., and Alpers, C.N. 2017. Challenges in recovering resources from acid mine drainage. https://www.imwa.info/docs/imwa_2017/ IMWA2017_Nordstrom_1138.pdf [accessed November 2017].

NoRval, D. and OBERHolster, R.E. 2011. Further processing and granulation of slags with entrained metal and high metal compound content, with specific reference to present manganese slag dumps as well as additions due to daily production. Southern African Pyrometallurgy. Jones, R.T and den Hoed, P. (eds.). Southern African Institute of Mining and Metallurgy. Johannesburg, South Africa. pp. 129-143.

NyiRENDA, R.L. 1991. The processing of steelmaking flue dust: A review. Minerals Engineering, vol. 4, no. 7-11. pp. 1003-1025.

Ongondo, F.O., Williams, I.D., and WhiтLock, G. 2015. Distinct urban mines: Exploiting secondary resources in unique anthropogenic spaces. Waste Management, vol. 45. pp. 4-9.

Palencia. I., Romero, R., Iglesias, N., and CARranza, F. 1999. Recycling of EAF dust leaching residue to the furnace: A simulation study. Journal of Materials, August. pp. 28-32.

Park, J., Jung, Y., Kusumah, P., LeE, J., and Kwon, K. 2014. Application of ionic liquids in hydrometallurgy. International Journal of Molecular Sciences, vol. 15. pp. 15320-15343.

Park, J.K., Clark, T., KRUEger, N., and Mahoney, J. 2017. A review of urban mining in the past, present and future. Advances in Recycling and Waste Management, vol. 2, no. 2. p. 127.

PARK, Y.J. and FRAY, D. 2009. Recovery of high purity precious metals from printed circuit boards. Journal of Hazardous Materials, vol. 164. pp. 1152-1158.

Pech-Canul, M.I. and Kongoli, F. 2016. The modified central paradigm of materials science and engineering in the extraction and development of new and recycled materials. Transaction of the Institute of Mining and Metallurgy Section C: Mineral Processing and Extractive Metallurgy C, vol. 125 , no. 4. pp. 238-241.

Phadke, H., Collins, A., Cotran, H., Glazer, S., Gorogniuk, A., Lavigne-Delville, J., Moin, N., Rodriguez, A., Rogers, J., and VozzA, G. 2014. Metals and mining research brief. Sustainability Accounting Standards Board. http://library.sasb.org/wp-content/uploads/NRR/NR0302_MetalsMining 2014_06_24_Industry_Brief.pdf [accessed 31 October 2014].

PERSON, R.A. 1971. Control of emissions from ferroalloy furnace processing. Journal of Metals, April. pp. 17-29.

Piatak, N.M., Parsons, M.B., and SeAl II, R.R. 2015. Characteristics and environmental aspects of slags: A review. Applied Geochemistry, vol. 57 pp. 236-266.

Ponsot, I. and Bernado, E. 2013. Self-glazed glass ceramic foams from metallurgical slag and recycled glass. Journal of Cleaner Production, vol. 59. pp. 245-250.

PRETorius, E.B. and NunNington, R.C. 2002. Stainless steel slag fundamentals From furnace to tundish. Ironmaking and Steelmaking, vol. 29, no. 2. pp. 133-139.

Purwanto, H. and AкIYAмA, T. 2006. Hydrogen production from biomass using hot slag. International Journal of Hydrogen Energy, vol. 31. pp. 491-495.

QuijornA, N., Miguel, G.S., and AndRes, A. 2011. Incorporation of Waelz slag into commercial ceramic bricks: A practical approach of industrial ecology. Industrial and Engineering Chemistry Research, vol. 50. pp. 5806-5814.

RANKIN, W.J. 2011. Minerals, Metals and Sustainability: Meeting Future Material Needs. CRC Press, Leiden, The Netherlands.

RASHAD, M.M. 2006. Synthesis and magnetic properties of manganese ferrite from low grade manganese ore. Materials Science and Engineering, vol. B127. pp. 123-129.

RawLings, R.D. 1994. Glass-ceramic matrix composites. Composites, vol. 25, no. 5. pp. 372-379.

RawLings, R.D., Wu, J.P., and BoccaccinI, A.R. 2006. Glass-ceramics: their production from wastes. A review. Journal of Materials Science, vol. 41, no. 3. pp. 733-761

RecK, B.K. and GRAEdeL, T.E. 2012. Challenges in metal recycling. Science, vol. 337, no. 6095. pp. 690-695

ReUTER, M., XIAO, Y., and BoIN, U. 2004. Recycling and environmental issues of metallurgical slags and salt fluxes. Proceedings of the VII International Conference on Molten Slags, Fluxes and Salts. Southern African Institute of Mining and Metallurgy, Johannesburg. pp. 349-356.

Remus, R., Mononet, M.A.A., Roudier, S., and SAnch, L.D. 2013. Best available techniques (BAT) reference document for iron and steel production. Industrial Emissions Directive 2010/75/EU. European Commission JRC Reference Report.

Republic of South Africa. 2018. Bill of Rights Chapter 2. Constitution of the Republic of South Africa. https://www.gov.za/documents/ constitution/chapter-2-bill-rights\#7 [accessed 27 January 2018]

Republic of South AfricA. 1991. Minerals Act (Act No. 50 of 1991). https://www.gov.za/sites/www.gov.za/files/a50_1991.pdf [accessed 27 January 2018].

RYcroft, M. 2014. Heat recovery from slag improves energy efficiency of furnaces. Energize, April 2014. pp. 55-57.

RZELEWSKA, M., BACZyŃSKA, M., WiśNIEWSKI, M., and RegEL-RoSocKA, M. 2017. Phosphonium ionic liquids as extractants for recovery of ruthenium (III) from acidic aqueous solutions. Chemical Papers, vol. 71, no. 6 . pp. 1065-1072. 


\section{Mining and metallurgical wastes: a review of recycling and re-use practices}

Salamati, S., Younesi, H., and Bahramifar, N. 2017. Synthesis of magnetic core-shell $\mathrm{Fe}_{4} \mathrm{O}_{4} @ \mathrm{TiO}_{2}$ nanoparticles from electric arc furnace dust for photocatalytic degradation of steel mill wastewater. RSC Advances, vol. 7 . pp. 19391-19405

Santos, R.M., Ling, D., Sarvaramini, A., Guo, M., Elsen, J., Larachi, F., Beaudoin, G., Blainpain, B., and van Gerven, T. 2012. Stabilization of basic oxygen furnace slag by hot stage carbonation treatment. Chemical Engineering Journal, vol. 203. pp. 239-250.

Semykina, A. and SeEtharaman, S. 2011. Recovery of manganese ferrite in nanoform from metallurgical slags. Metallurgical and Materials Transactions B, vol. 42. pp. 2-4.

SEMYкinA, A. 2013. Recovery of iron and manganese values from metallurgical slags by oxidation route. Doctoral thesis, Department of Materials Science and Engineering, Royal Institute of Technology, Stockholm, Sweden.

SHARMA, U.S., SHARMA, R.N., and SHAH, R. 2014. Physical and magnetic properties of manganese ferrite nanoparticles. International Journal of Engineering Research and Applications, vol. 4, no. 8. pp. 14-17.

Shatokha, V., Semykina, A., Nakano, J., SRidhar, S., and Seetharaman, S. 2013. A study on transformation of some transition metal oxides in molten steelmaking slag to magnetically susceptible compounds. Journal of Mining and Metallurgy B, vol. 49, no. 2. pp. 169-174.

SHIH, K., WHITE, T., and LecKIE, J.O. 2006. Nickel stabilization efficiency of aluminate and ferrite spinels and their leaching behavior. Environmental Science and Technology, vol. 40, no. 17. pp. 5520-5526.

SimAte, G.S. and NdLovu, S. 2014. Acid mine drainage: Challenges and opportunities. Journal of Environmental Chemical Engineering, vol. 2. pp. 1785-1803.

Simate, G.S., Maledi, N., Ochieng, A., Ndlovu, S., Zhang, J., and Walubita, L.F. 2016. Coal-based adsorbents for water and wastewater treatment. Journal of Environmental Chemical Engineering, vol. 4. pp. 2291-2312.

Stathopoulos, V.N., Papandreou, A., Kanellopoulou, D., and Stournaras, C.J. 2013. Structural ceramics containing electric arc furnace dust. Journal of Hazardous Materials. vol. 262. pp. 91-99.

STEER, J.M. and GRIFFITHS, A.J. 2013. Investigation of carboxylic acids and nonaqueous solvents for the selective leaching of zinc from blast furnace dust slurry. Hydrometallurgy, vol. 140. pp. 34-41.

Sugimoto, M. 1999. The past, present and future of ferrites. Journal of the American Ceramic Society, vol. 82, no. 2. pp. 269-280.

Sun, Y., SRIDAH, S., Liu, L., WANG, X., and ZhANG, Z. 2015a. Integration of coal gasification and waste heat recovery from high temperature steel slag: an emerging strategy to emission reduction. Scientific Reports, vol. 5. pp. 1-11.

Sun, Y., ZHANG, Z., Liu, L., and WANG, X. 2015b. Heat recovery from high temperature slags: A review of chemical methods. Energies, vol. 8. pp. 1917-1935.

Sun, Y., Zhang, Z., Seetharaman, S., Liu, L. and Wang, X. 2015c. Characteristics of of low temperature biomass gasification and syngas release behavior using hot slag. Royal Society of Chemistry Advances, vol. 4. pp. 62105-62114.

Sun, Z.H.I., Xiao, Y., SietSma, J., Agterhuis, H., Visser, G., and Yang, Y. 2015d. Characterization of metals in the electronic waste of complex mixtures of end-of-life ICT products for development of cleaner recovery technology. Waste Management, vol. 35. pp. 227-235.

Sun, Z.H.I., Xiao, Y., Sietsma, J., Agterhuis, H., and Yang, Y. 2015e. A cleaner process for selective recovery of valuable metals from electronic waste of complex mixtures of end-of-life electronic products. Environmental Science and Technology, vol. 49. pp. 7981-7988.

Sun, Z.H.I., XiAo, Y., SieTsma, J., Agterhuis, H., and YAnG, Y. 2016a. Recycling of metals from urban mines: A strategic evaluation. Journal of Cleaner Production, vol. 112. pp. 2977-2987.

Sun, Y., SeEtharaman, S., Liu, Q., and Zhang, Z. 2016b. Integrated biomass gasification using the waste heat from hot slags: Control of syngas and polluting gas releases. Energy, vol. 114. pp. 165-176.

Sun, Y., Liu, Q., WANG, H., ZHANG, Z., and WANG, X. 2017. Role of steel slags on biomass/carbon dioxide gasification integrated with recovery of high temperature heat. Bioresource Technology, vol. 223. pp. 1-9.

Sun, P. and Guo, Z. 2015. Sintering of porous sound absorbing materials from steel slag. Transactions of Nonferrous Metallurgical Society of China, vol. 25. pp. 2230-2240.

SuZUKI, M., TANAKA, T., and YAMASAKI, N. 2014. Use of hydrothermal reactions for slag/glass recycling to fabricate porous materials. Current Opinion in Chemical Engineering, vol. 3, no. 7. pp. 7-12.

SYED, S. 2006. A green technology for recovery of gold from non-metallic secondary resources. Hydrometallurgy, vol. 82. pp.48-53.

TANaKa, T., YoshiKawa, T. and SuzuKI, M. 2009. Design of porous glass and slag materials and its applications to refining. Proceedings of the 8th International Conference on Molten Slags, Fluxes, and Salts, San Diego, Chile. pp. 555-564

TANGSTAD, M. 2013. Manganese ferroalloys technology. Handbook of Ferroalloys: Theory and Technology. Gasik, M. (ed.). ButterworthHeinemann Elsevier, Oxford, UK.

TANSKAnen, P. and MaKкonen, H. 2006. Design of slag mineralogy and petrology: Examples of useful methods for slag composition and property design. Global Slag Magazine, vol. 5. pp. 16-20.

TilbuRY, D. 1995. Environmental education for sustainability: Defining the new focus of environmental education in the 1990s. Environmental Education Research, vol. 1, no. 2. pp. 195-212.

Tuncuk, A., Stazi, V., AKcil, A., Yazici, E.Y., and Deveci, H. 2012. Aqueous metal recovery techniques from e-scrap: Hydrometallurgy in recycling. Minerals Engineering, vol. 25. pp. 28-37.

UNESCO. 2017. Education for Sustainable Development: Learning Objectives. Education 2030 and UNESCO Publishing. http://unesdoc.unesco.org/ images/0024/002474/ 247444e.pdf [accessed 24 November 2017].

UNESCO. 2010. Engineering: Issues, Challenges and Opportunities for Development. UNESCO Report, UNESCO Publishing. http://unesdoc.unesco.org/images/0018/001897/ 189753e.pdf [accessed 23 November 2017]

VANDERBURG, W.H. 1999. On the measurement and integration of sustainability in engineering education. Journal of Engineering Education, vol. 88, no. 2 . pp. 231-235.

Viart, N., Pourroy, G., Greneche, J.M., Niznasky, D., and Hommet, J. 2000. Microstructural and magnetic properties of $\mathrm{Fe} / \mathrm{Cr}$-substituted ferrite composites. The European Physical Journal Applied Physics, vol. 12 pp. 37-46.

Vieira, C.M.F., SAnchez, R., Monteiro, S.N., Lalla, N., and QuARANTA, N. 2013. Recycling of electric arc furnace dust into red ceramic. Journal of Materials Research and Technology, vol. 2, no. 2. pp. 88-92.

WANG, H., GAO, J., LIU, W., ZHANG, M., and Guo, M. 2016a. Recovery of metaldoped zinc ferrite from zinc-containing electric arc furnace dust: Process development and examination of elemental migration. Hydrometallurgy, vol. 166. pp. 1-8.

WANG, H., LI, Y., GAO, M., ZHANG, M. and Guo, M. 2016b. A novel hydrothermal method for zinc extraction and separation from zinc ferrite and electric arc furnace dust. International Journal of Minerals Metallurgy and Materials, vol. 23 , no. 2. pp. 146-155.

Wang, H., Liu, W., JiA, N., Zhang, M., and Guo, M. 2017a. Facile synthesis of metal-doped Ni-Zn ferrite from treated $\mathrm{Zn}$-containing electric arc furnace dust. Ceramics International, vol. 43. pp. 1980-1987.

WAng, M., TAN, Q., Ching, J.F. and LI, J. 2017b. Recovery of rare and precious metals from urban mines: A review. Frontiers of Environmental Science and Engineering, vol. 11, no. 5. pp. 1-17.

World Steel Association. 2015. Steel in the circular economy: A life cycle perspective. https://www.worldsteel.org/en/dam/jcr:00892d89-551e42d9-ae68-abdbd3b507a1/Steel+in+the+circular+economy++A+life+cycle+perspective.pdf [accessed 31 October 2017].

XING, P., MA, B., WANG, C., and CHEN, Y. 2017. Cleaning of lead smelting flue gas scrubber sludge and recovery of lead, selenium and mercury by the hydrometallurgical route. Environmental Technology, May. pp. 1-9.

Yakornov, S.A., Pan'shin, A.M., Grudinsky, P.I., Dyubanov, V.G., Leon'tev, L.I., KozLov, P.A., and IvaKIN, D.A. 2017. Thermodynamic analysis of zinc ferrite decomposition in electric arc furnace dust by lime. Russian Journal of Non-Ferrous Metals, vol. 58, no. 6. pp. 586-590.

YANG, X., ZHANG, J., and FANG, X. 2014. Rare earth element recycling from waste nickel-metal hydride batteries. Journal of Hazardous Materials vol. 279. pp. 384-388

Zhang, H., Wang, H., Zhu, X., Oiu, Y.J., Li, K., Chen, R., and Liao, O. 2013. A review of waste heat recovery technologies towards molten slag in steel industry. Applied Energy, vol. 112. pp. 956-966.

Zhang, W., Zuo, X., Zhang, D., Wu, C., and Silva, S.R.P. 2016. Cr3+ substituted spinel ferrite nanoparticles with high coercivity. Nanotechnology, vol. 27. pp. 1-8.

Zimmerman, J.B. and ANASTAS, P.T. 2009. Integrating Green Engineering into Engineering. Green Chemistry Education, ACS Symposium Series, vol. 1011. pp. 137-146.

ZoLLER, U. 2013. Science, technology, environment, Society (STES) literacy for sustainability: What should it take in Chem/Science education. Emergent Topics in Chemistry Education, vol. 24, no. 2. pp. 207-214.

ZANotTo, E.D. 2010. A bright future for glass-ceramics. American Ceramic Society Bulletin, vol. 89, no. 8. pp. 19-27. 